\title{
AUNC
}

Zabytkoznawstwo i Konserwatorstwo XLVII

Toruń 2016

DOI: http://dx.doi.org/10.12775/AUNC_ZiK.2016.003

\section{Problemy odbudowy \\ kościoła pw. św. Mikołaja w Wolinie w latach 1989-2000}

\author{
JANUSZ GIERLASIŃSKI \\ Pracownia Historii Architektury, Wydział Sztuk Pięknych, UMK w Toruniu \\ e-mail: jangier@umk.pl
}

Keywords: monument; cultural heritage; war damages; rebuilding of sacred buildings

Słowa kluczowe: zabytek; dziedzictwo kultury; zniszczenia wojenne; odbudowa budowli sakralnych.

\begin{abstract}
The issues concerning the rebuilding of the St Nicholas' church in Wolin between 1989-2000

We can state with a high probability that on the grounds of what is now the Archdiocese of Szczecin-Kamien (former Szczecin Voivodeship) about 200 sacred buildings were turned to ruins during the Second World War. The rebuilding of the St Nicholas' church ruins in Wolin is one example of the longstanding and rightly taken the struggle to save and rebuild monuments of architecture of the past eras, mementoes that bear testimony of the Western Pomerania's artistic achievements, monuments representing the cultural heritage of humanity. The rebuilding (reconstruction) itself of the historic architecture is debatable, however, after the Second World War as a certain phenomenon it was justified. The former trends of conservation thought, which worked well in "normal times" couldn't withstand a clash with the conviction that we should not retain the ruins of war. In the case of sacred buildings an important factor influencing the state of their preservation and the process of rebuilding were the relations between the state and the Catholic Church, and the policy of the state authorities, including conservation services. After many years of efforts, in 1988 the
\end{abstract}


ruins of St Nicholas' church were handed over to the Catholic Church. Preparing the rebuilding project, the team of architects was guided by the principle of the pre-war form reconstruction. The rebuilding work was completed in 2000.

\section{Abstrakt}

Można z dużym prawdopodobieństwem stwierdzić, że na terenie obecnej archidiecezji szczecińsko-kamieńskiej (dawne województwo szczecińskie) w czasie drugiej wojny światowej w ruinę obrócono około 200 budowli sakralnych. Odbudowa kościoła p.w. św. Mikołaja w Wolinie to jeden z przykładów długoletniej i słusznie podjętej batalii na rzecz ratowania i odbudowy pomników architektury minionych epok, pamiątek świadczących o dorobku artystycznym Pomorza Zachodniego, zabytków stanowiących dziedzictwo kulturowe ludzkości. Sama odbudowa (rekonstrukcja) zabytkowej architektury jest dyskusyjnym zagadnieniem, jednak po drugiej wojnie światowej, jako pewien fenomen, była uzasadniona. Dawne kierunki myśli konserwatorskiej, które sprawdzały się w „zwykłych czasach”, nie wytrzymywały zderzenia z przekonaniem, że nie powinno się zachowywać ruin wojennych. W przypadku budowli sakralnych istotnym czynnikiem wpływającym na stan ich zachowania oraz odbudowę były relacje między państwem a Kościołem katolickim oraz polityka władz państwowych, w tym służb konserwatorskich. Po długoletnich staraniach, w 1988 roku ruiny świątyni św. Mikołaja zostały przekazane Kościołowi katolickiemu. Zespół architektów przygotowując projekt odbudowy kierował się wyznaczoną przez konserwatora wojewódzkiego w Szczecinie generalną zasadą rekonstrukcji bryły kościoła według stanu sprzed 1945 roku. Prace przy odbudowie zakończono w 2000 roku.

„136 - Wolin - kościół gotycki z XIV wieku, w ruinie po ostatniej wojnie, jedyny zabytek w tym mieście, przed kilku laty rozebrano już tam inny kościół gotycki [św. Jerzego - J.G.] też będący w ruinie. Pomysł zabezpieczenia ruiny trwałej w naszym klimacie jest nierealny. Tak argumentował ks. Kostynowicz, a p. Kołodziejek powoływał się na opinię W[ojewódzkiego] K[onserwatora] Z[abytków], że obiekt ten nie nadaje się już do odbudowy. P. dyr. Merker oświadczył, że Urząd rozpatrzy tę sprawę"1. Przytoczony fragment dyskusji dobrze ilustruje sytuację zabytkowych budowli sakralnych na Ziemiach Zachodnich i Północnych w okresie Polskiej Rzeczypospolitej Ludowej. Przy oczywistych uwarunkowaniach społecznych i gospodarczych, zasadniczy wpływ na położenie kościołów i stan ich zachowania miały, jak się wydaje,

Archiwum Konserwatora Diecezji Szczecińsko-Kamieńskiej (dalej: AKDSK), teczka Rozmowy 19.11.1973 w Urzędzie do Spraw Wyznań (dalej: UdSW) Wojewody Szczecińskiego, 22.12.1973, Protokół rozmów przeprowadzonych 19.11.1973 w UdSW w Warszawie w sprawie niektórych pozycji z art. 2 diecezji szczecińsko-kamieńskiej. 
relacje między państwem a Kościołem katolickim, bezpośrednio zaś działania władz partyjnych i państwowych oraz służb konserwatorskich ${ }^{2}$.

W czasie drugiej wojny światowej wiele kościołów na Pomorzu Zachodnim uległo poważnym zniszczeniom ${ }^{3}$. Po zakończeniu działań wojennych liczne świątynie rozebrano częściowo bądź w całości ${ }^{4}$, inne zostały zdewastowane ${ }^{5}$. Jednym z przykładów skomplikowanych losów pomorskich budowli sakralnych w okresie PRL jest powojenna historia kościoła pw. św. Mikołaja w Wolinie.

Ostatnią przebudowę tej świątyni zakończono u schyłku XIX wieku ${ }^{6}$. W roku 1945 w wyniku bombardowania zostały zniszczone dach i stropy nad korpusem oraz drewniana konstrukcja zwieńczenia wieży wraz $\mathrm{z}$ hełmem, runęła górna część wschodniego szczytu i trzy filary nawy południowej,

2 Np. krótko po VIII plenum partii w 1956 r. zaproponowano założenie w UdSW „komórki koncepcyjnej” z zadaniem opracowywania planów działania i polityki wobec Kościoła. Por. Polska Biblioteka Internetowa, Protokół nr 171, k. 89, Wytyczne stanowiska partii w sprawie stosunków między państwem a Kościołem; Archiwum Diecezji Zielonogórsko-Gorzowskiej (dalej: ADZG), sygn. 1093, Korespondencja z władzami świeckimi 1963-1972, W imieniu księży dekanalnych dziekani (3.06.1965), Do Rządu Polskiej Rzeczypospolitej Ludowej na ręce premiera Józefa Cyrankiewicza Warszawa; Instytut Pamięci Narodowej (dalej: IPN), sygn. 048/1, UdSW, Warszawa, 12.01 .1973 (tajne), Do Prezydium Wojewódzkiej Rady Narodowej Wydział ds. Wyznań Szczecin, k. 2-4; Kazimierz Kozłowski, Źródła do dziejów Pomorza Zachodniego, t. 14 (Szczecin: Uniwersytet Szczeciński, 2007), 178-186: „1973 grudzień 28, Warszawa, Fragmenty sprawozdania ze spotkania biskupów ziem zachodnich i północnych z wiceministrem Józefem Tejchmą"; Archiwum Wojewódzkiego Urzędu Ochrony Zabytków w Szczecinie (dalej: AWUOZS), sygn. II/243, k. 131, 132, 133; AWUOZS, sygn. II/41, Wykaz obiektów zabytkowych (kościoły i kaplice) przeznaczonych do rozbiórki.

3 Np. kościoły: pw. św. Jakuba w Szczecinie, pw. NMP Królowej Świata w Stargardzie Szczecińskim, pw. Wniebowzięcia NMP w Pyrzycach, pw. MB Królowej Polski w Starym Chrapowie, pw. Narodzenia NMP w Smolnicy, pw. Narodzenia NMP w Choszcznie, pw. św. Katarzyny w Goleniowie.

4 Zob. Krystyna Bastowska, „Dzieje zabytkowych świątyń dawnego województwa koszalińskiego w latach 1945-1989”, w Społeczeństwo - państwo - Kościół (1945-1989). Materiały ogólnopolskiej konferencji naukowej, Szczecin, 15-16 VI 2000, red. Arkadiusz Kawecki, Krzysztof Kowalczyk i Artur Kubaj (Szczecin: Stowarzyszenie Absolwentów US, 2000), 8894; Janina Kochanowska, „Losy zabytków sakralnych Pomorza Zachodniego podczas wojny i w pierwszych latach po wojnie”, w Wspólne dziedzictwo? Ze studiów nad stosunkiem do spuścizny kulturowej na Ziemiach Zachodnich, red. Zbigniew Mazur (Poznań: Instytut Zachodni, 2000), 221-222.

5 Np. kościoły w Dłusku, Dobrkowie, Olchowie, Kościnie, Lubiatowie, AWUOZS, sygn. II/41, k. 3 i bp.; AWUOZS, sygn. II/210, k. 392; kościół w Oborzanach (wykorzystywany jako pomieszczenie dla bydła), zob. Kochanowska, „Losy zabytków”, 227.

6 Wyburzono całkowicie ściany naw bocznych, odbudowując je w formach neogotyckich, podobnie jak zwieńczenie szczytu wschodniego; posadowiono nowy hełm wieży, nawiązujący do XVII-wiecznej przebudowy. 
uszkodzone były mury kapitelne korpusu i wieży oraz pozostałe filary wraz ze ścianą arkadową nad nimi, rozspoiły się mury wzdłużne od ich poprzecznych powiązań, a także część przypór ${ }^{7}$. Według oszacowań zakres zniszczeń obiektu sięgał pięćdziesięciu procent ${ }^{8}$. Niewykonanie prac zabezpieczających przyczyniło się do znaczącego pogorszenia stanu zachowania kościoła. Wpływ na postępującą destrukcję budowli miały również czynniki atmosferyczne (il. 2). Dodatkowo świątynia przez dekady była poddawana niszczycielskiej działalności ludzi ${ }^{9}$; m.in. w 1972 roku rozebrano partie ścian południowej i zachodniej, które były w zupełnie dobrym stanie ${ }^{10}$.

Administratorzy Kościoła katolickiego na Pomorzu Zachodnim wielokrotnie zwracali się do władz państwowych PRL w sprawie przekazania ruiny świątyni ${ }^{11}$, lecz ich wnioski przez kilkadziesiąt lat były rozpatrywane negatywnie. Kierownictwo Wydziału do Spraw Wyznań w Szczecinie jako argumentu uzasadniającego odmowę używało najczęściej opinii Wojewódzkiego Konserwatora Zabytków w Szczecinie stwierdzającej, że obiekt nie nadaje się już do odbudowy ${ }^{12}$. Zasadniczo decyzje wydziałów do spraw wyznań miały na celu zachowanie stanu posiadania Skarbu Państwa. W związku z tym starały się ograniczać możliwości przekazania obiektów kościelnym osobom prawnym, jednocześnie szermując liczbą świątyń, które stronie kościelnej udało się odzyskać. Na przykład podkreślano, że w latach siedemdziesią-

AWUOZS, teczka Kościół pw. św. Mikołaja w Wolinie, Projekt koncepcyjny odbudowy - część ogólna, Parafia Rzymsko-Katolicka pw. św. Stanisława w Wolinie. Kościół pw. św. Mikołaja w Wolinie, ul. Wojska Polskiego, Projekt koncepcyjny odbudowy, Zespół autorski: mgr inż. arch. Zbigniew Becker, mgr inż. arch. Irena Kukla, inż. arch. Stefan Kwilecki, mgr Bogdana Kozińska pod kierunkiem mgr. inż. arch. Janusza Nekanda-Trepki, Szczecin 1989, s. 6.

8 AWUOZS, Karta Obiektu Zabytkowego (dalej: KOZ), Kościół pw. św. Mikołaja. Wolin, Szczecin 1959(?).

9 O losach świątyni w latach 1945-1989 zob. Janusz Gierlasiński, „Kościół św. Mikołaja w Wolinie. Losy budowli w latach 1945-1988", Acta Universitatis Nicolai Copernici. Zabytkoznawstwo i Konserwatorstwo 46 (2015): 265-286.

10 Kazimiera Kalita, fot. Grzegorz Solecki, „Kościół św. Mikołaja. Dokumentacja historyczno-architektoniczna” (PP PKZ, Szczecin 1973), 32. Zob. też Maria Bujwid, „Kościół św. Mikołaja. Kosztorys - wstępna wycena” (PP PKZ, Szczecin 1972); Tadeusz Zajączkowski, „Kościół św. Mikołaja. Projekt ramy zabezpieczającej” (PP PKZ, Szczecin 1973).

11 Np. AKDSK, teczka Art. 1, Art. 2+sprawy dodatkowe, Art. 2. II kwestionariusz, Art. 2. III kwestionariusz, Wykaz nieruchomości z obiektami sakralnymi niebędącymi w użytkowaniu Kościoła katolickiego, poz. 136; AKDSK, teczka Ruiny - 1985, Wypis najbardziej zagrożonych ruin z pisma, które wniósł biskup szczecińsko-kamieński 9.08.1982, Znak: L2-6/82 do Pana Ministra - Kierownika UdSW; Notatka służbowa z rozmów przeprowadzonych 27.09.1985 w UdSW w Warszawie.

12 Kozłowski, Źródła, 175. 
tych oddano Kościołowi ponad siedemdziesiąt zniszczonych świątyń - ich odbudowa wiązała się z ogromnym obciążeniem finansowym i problemami zaopatrzeniowymi.

W roku 1986 ks. prałat Andrzej Majewicz, administrator parafii pw. św. Stanisława Biskupa i Męczennika w Wolinie, złożył do naczelnika miasta i gminy w Wolinie prośbę o przekazanie w użytkowanie wieczyste ruiny obiektu sakralnego wraz z przynależnym geodezyjnie terenem ${ }^{13}$. W myśl obowiązujących wówczas przepisów władze lokalne wszczęły procedurę mającą na celu określenie kosztów użytkowania wieczystego gruntu oraz wartości stojącej na nim ruiny kościoła, która miała być sprzedana parafii ${ }^{14}$. W decyzji z grudnia 1986 roku naczelnik miasta i gminy Wolin postanowił oddać wspomniane grunty w użytkowanie wieczyste oraz sprzedać ruinę kościoła na rzecz parafii św. Stanisława B. M. w Wolinie reprezentowanej przez ks. Jana Ubermana ${ }^{15}$, ustalając wartość ruiny na niebagatelną kwotę ponad trzech milionów złotych (dokładnie: 3141712 zł) (il. 3). Naczelnik postanowił także o zastosowaniu pięćdziesięcioprocentowej zniżki na cenę ruiny ze względu na jej zabytkowy charakter, potwierdzony wpisem do rejestru zabytków ${ }^{16}$. W decyzji zobowiązano wieczystego użytkownika działki do odbudowy ruiny kościoła i użyt-

13 AKDSK, teczka Ruiny - 1985, Rzymsko-Katolicka Parafia [...], Wolin 28.01.1986, Naczelnik Urzędu Miasta i Gminy Wolin, „Rzymsko-Katolicka Parafia p.w. św. Stanisława B.M. w Wolinie prosi o przekazanie jej w użytkowanie wieczyste ruiny obiektu sakralnego wraz z przynależnym geodezyjnie terenem w miejscowości Wolin. Obiekt sakralny nosi nazwę Ruiny Kościoła św. Mikołaja w Wolinie. [...] Wniosek ten wysyła parafia zgodnie z ustaleniami Kurii Biskupiej Szczecińsko-Kamieńskiej z Dyrektorem ds. Wyznań Urzędu Wojewódzkiego w Szczecinie dnia 8.01.1986". W 1985 r. bp Jan Gałecki, wikariusz generalny, wystąpił z podobnym wnioskiem do naczelnika Wolina, zob. AKDSK, teczka Ruiny kościołów, Pisma do UdSW w sprawie ruin, Kuria Biskupia Szczecińsko-Kamieńska, 15.10.1985, Znak: L 2-20/85, Naczelnik Urzędu Miasta i Gminy Wolin.

14 Zob. AKDSK, teczka Ruiny - 1985, Naczelnik Miasta i Gminy Wolin, Urząd Wojewódzki Wydział Geodezji i Gospodarki Gruntami ul. Mickiewicza 41, 70-383 Szczecin, Nasz znak: G. 8228-1/86, Wolin, 1986.03.20; Z-ca Naczelnika Miasta i Gminy w Wolinie, Ob. mgr inż. Romuald Piątkowski, ul. [...], Nasz znak: G. 8228-1/86, Data: 1986.05.28; Z-ca Naczelnika Miasta i Gminy w Wolinie, Parafia św. Stanisława B.M. w Wolinie, Nasz znak: G. 8228-1/86, Data: 1986.05.28. Na spotkaniu w 1980 r. dyrektor Wydziału ds. Wyznań w Szczecinie oświadczył, że nie ma możliwości wykorzystania dawnych przepisów w sprawie przekazania ruin. Zob. AKDSK, teczka Szczecin, Protokół rozmów, jakie odbył ks. Roman Kostynowicz z dyrektorem Wydziału do Spraw Wyznań Henrykiem Kołodziejkiem 5.12.1980, s. 2.

15 Proboszcz parafii św. Stanisława B.M. w Wolinie od 14.07.1986 r.

16 AKDSK, teczka Dekanat Wolin par. pw. św. Stanisława B.M. Wolin, Naczelnik Miasta i Gminy Wolin, Decyzja G. 8228-1/86, Data: 1986.12.06; Naczelnik Miasta i Gminy Wolin, Postanowienie G 8228-1/86; AWUOZS, KOZ, Kościół pw. św. Mikołaja, Wolin, 1959 - Rejestr zabytku 374/1959. 
kowania obiektu zgodnie z przeznaczeniem. Parafia zaskarżyła wydaną decyzję do organu wyższej instancji. Dyrektor Wydziału Geodezji i Gospodarki Gruntami Urzędu Wojewódzkiego w Szczecinie uznał argumenty skarżącego i w swojej decyzji stwierdził, że terenowy organ administracji państwowej w sposób rażący naruszył przepisy prawa. Naczelnik w Wolinie bowiem orzekł o sprzedaży na własność ruiny kościoła i ustalił wartość sprzedawanych ruin. Tymczasem, zgodnie z literą prawa, terenowy organ administracji państwowej mógł ustalać cenę sprzedaży jedynie domu i innych budynków oraz lokali i urządzeń - według kosztów ich odtworzenia pomniejszonych o stopień zużycia ${ }^{17}$. Mimo takiej wykładni przepisów przez dyrektora Wydziału Geodezji i Gospodarki Gruntami Urzędu Wojewódzkiego w Szczecinie, kolejna decyzja naczelnika miasta i gminy Wolin była dla parafii równie niekorzystna. Utrzymał on naliczoną kwotę zakupu ruin z uzasadnieniem, że „ustalono ją biorąc pod uwagę koszt odtworzenia i wybudowania od podstaw tych fragmentów substancji budowlanej, która pozostaje zachowana"18. Postawa naczelnika z Wolina świadczyła, że jeszcze u schyłku lat osiemdziesiątych w ramach prowadzonej polityki wyznaniowej państwo chciało decydować również o statusie i stanie zachowania obiektów sakralnych, w tym ich ruin.

Ostateczną decyzję woliński naczelnik podjął 11 marca 1988 roku $^{19}$. Zgodnie z jego postanowieniem grunt został oddany w użytkowanie wieczyste, czyli na dziewięćdziesiąt dziewięć lat, opłatę za użytkowanie ustalono na najniższym poziomie, co zaś najważniejsze, odstąpiono od sprzedaży zabytkowej ruiny i przekazano ją Kościołowi nieodpłatnie. Tym samym naczel-

17 AKDSK, teczka Dekanat Wolin, Urząd Wojewódzki w Szczecinie Wydział Geodezji i Gospodarki Gruntami, Decyzja GMS 8224/6/87, Data: 1987.06.12, „Orzekam uchylić zaskarżoną decyzję w całości i przekazać sprawę do ponownego rozstrzygnięcia przez organ pierwszej instancji. Z dokonanych ustaleń wynika, że zaskarżona decyzja Naczelnika Miasta i Gminy w Wolinie z 6.12.1986, nr G.8228-1/86, rażąco narusza zarówno przepisy ustawy [...] o gospodarce gruntami i wywłaszczeniu nieruchomości [...], jak też przepisy kodeksu postępowania administracyjnego. Rażące naruszenie prawa materialnego przez organ pierwszej instancji polega na tym, że rozstrzygnięcie omawianej decyzji jest sprzeczne z przepisami [...], które stanowią, iż: terenowy organ administracji państwowej, w drodze decyzji, ustala cenę sprzedaży domu i innych budynków oraz lokali i urządzeń - według kosztów ich odtworzenia i pomniejszonych o stopień zużycia. Wbrew tej zasadzie Naczelnik Miasta i Gminy Wolin orzekł sprzedać na własność ruiny [wyróżn. oryg.] kościoła i ustalić wartość sprzedanych ruin kościoła".

18 AKDSK, teczka Dekanat Wolin, Naczelnik Miasta i Gminy w Wolinie, Decyzja G. 8228-4/87, Wolin, 1987.09.10.

19 Należy przypuszczać, że sprawy przybrały taki obrót w wyniku rozmów prowadzonych nieoficjalnie. 
nik miasta i gminy w Wolinie uznał wykładnię dyrektora Wydziału Geodezji i Gospodarki Gruntami Urzędu Wojewódzkiego w Szczecinie i potwierdził - co zresztą było oczywiste - że na gruntach będących przedmiotem sprawy znajdowały się ruiny świątyni, które ze względu na wysoki stopień zniszczenia (blisko 100\%) nie stanowiły obiektu budowlanego, a koszt rozbiórki byłby znacznie wyższy niż wartość odzyskanego materiału budowlanego. Ponadto ruiny nie mogły być rozebrane, gdyż stanowiły obiekt zabytkowy wpisany do rejestru zabytków ${ }^{20}$. Decyzja dotycząca ruin kościoła w Wolinie stała się swego rodzaju wzorcowym zbiorem wytycznych do sporządzania ewentualnych wniosków o przekazanie innych ruin obiektów sakralnych wraz z przynależną geodezyjnie działką ${ }^{21}$.

W czerwcu 1988 roku ks. proboszcz Jan Uberman skierował do Wojewódzkiego Konserwatora Zabytków w Szczecinie pismo w sprawie określenia wytycznych do odbudowy kościoła w Wolinie, zaznaczając, że „obecna ruina ma spełniać funkcje sakralne" ${ }^{22}$. W odpowiedzi konserwator wojewódzki oświadczył, „że wytyczne konserwatorskie przesłane zostaną jednostce autorskiej po ostatecznych ustaleniach z Kurią Biskupią na temat koncepcji odbudowy" ${ }^{23}$. Dwa miesiące później w Szczecinie doszło do spotkania w sprawie odbudowy ruiny kościoła. Uczestniczący w nim ks. Roman Kostynowicz (Konserwator Diecezjalny), mgr Krystyna Loose (Konserwator Wojewódzki) oraz ks. Jan Uberman rozważali między innymi możliwość rekonstrukcji sklepień, ustalili wstępnie formy kształtek. Ekspertyzę konstrukcyjną miał wykonać inż. Mirosław Hamberg. Brano pod uwagę dwa warianty przyszłej konstrukcji więźby dachowej - stalową lub drewnianą; według uczestników spotkania lepszym rozwiązaniem miało być zastosowanie więźby drewnianej. Założono, że świątynia zostanie odbudowana na zasadzie rekonstrukcji, biorąc pod uwagę możliwość wykorzystania współczesnych materiałów do uczytelnienia odbudowy. Zdecydowano o zaangażowaniu inż. arch. Janusza Nekanda-Trepki wraz z zespołem do przygotowania projektu odbudowy oraz

20 AKDSK, teczka Ruiny - 1985, Naczelnik Miasta i Gminy Wolin, Decyzja G 8224-5/88, Data: 1988.03.11.

21 AKDSK, teczka Ruiny - 1985, Szczecin, 4.04.1989, Znak: L 2 - 39/89, Przewielebny Księże Proboszczu.

22 AWUOZS, sygn. 1202, Rzymsko-Katolicka Parafia pw. św. Stanisława B.M., L.dz. 8/88[?], Do Wojewódzkiego Konserwatora Zabytków w Szczecinie.

23 AWUOZS, sygn. 1202, Urząd Wojewódzki Wydział Kultury i Sztuki, Wojewódzki Konserwator Zabytków Szczecin, Szczecin, 1988.07.07, Parafia Rzymsko-Katolicka pw. św. Stanisława B.M., ul. Kościelna 19, 72-500 Wolin. 
nadzorowania inwestycji ${ }^{24}$. W trakcie spotkania okazało się, że obiekt nie został zinwentaryzowany, parafia natomiast dysponuje kosztorysem odbudowy sporządzonym przez p. Ziółkowskiego w 1983 roku. Według wyliczeń inwestycja miała pochłonąć kwotę 45923 tys. $z^{25}$. We wrześniu 1988 roku Kuria Biskupia Archidiecezji Szczecińsko-Kamieńskiej wydała polecenie odbudowy zniszczonej świątyni ${ }^{26}$.

W pierwszej połowie 1989 roku zespół autorski w składzie: mgr inż. arch. Zbigniew Becker, mgr inż. arch. Irena Kukla, inż. arch. Stefan Kwilecki, mgr (obecnie dr, historyk sztuki) Bogdana Kozińska pod kierunkiem mgr. inż. arch. Janusza Nekanda-Trepki przygotował część ogólną projektu koncepcyjnego odbudowy wolińskiego kościoła. Na podstawie wcześniejszych opracowań dokumentacyjno-historycznych ${ }^{27}$, dostępnego materiału ikonograficznego ${ }^{28}$ oraz badań strukturalnych zabytku przeprowadzonych przed przystąpieniem do prac projektowych, sformułowano wytyczne zapewniające „spełnienie podstawowych wymogów konserwatorskich, ciążących na projektantach odbudowy"29. Znaczne zniszczenia i ubytki w strukturze budowli oraz bardzo skromne zasoby dokumentacji ikonograficznej unaoczniły zespołowi, jak dalece skomplikowane było to zamierzenie. Mimo trudności udało się ustalić zasadnicze założenia. Do najważniejszych należała z pewnością generalna zasada zachowania i ochrony wszystkich elementów dawnej struktury budowli, łącznie z pochodzącymi z drugiej połowy XIX wieku. Słusznie przyjęto, że dziewiętnastowieczną przebudowę należy traktować jako jedną z faz przemian zachodzących w strukturze świątyni. Można bowiem powiedzieć, że następujące po sobie fazy są świadectwem wkładu kolejnych pokoleń architektów i budowniczych zarówno w formę bryły obiektu, jak i rzeźby jego

24 AKDSK, teczka Dekanat Wolin, Parafia pw. św. Stanisława B.M., Wolin, Szczecin, 18.08.1988. Zebranie w sprawie odbudowy kościoła św. Mikołaja w Wolinie. W zebraniu uczestniczył m.in. Diecezjalny Konserwator Zabytków ks. mgr Roman Kostynowicz.

25 Zob. AKDSK, teczka Obiekt - ruina obiektu sakralnego, Miejscowość - Wolin, województwo - szczecińskie, B. Część kosztorysowa.

26 AKDSK, teczka Dekanat Wolin, Sprawozdanie z przekazania i odbioru obiektu sakralnego. Konserwator wojewódzki dnia 18.10 .1988 pozytywnie zaopiniował odbudowę kościoła w Wolinie do wskazania lokalizacyjnego dla odbudowy ruin. Zob. AWUOZS, sygn. 1202, Urząd Wojewódzki Wydział Kultury i Sztuki, Wojewódzki Konserwator Zbytków, Szczecin, 1988.10.18, Kl. 3-5342/120/88, Urząd Wojewódzki Wydział Planowania Przestrzennego, Urbanistyki, Architektury i Nadzoru Budowlanego w miejscu.

27 Zob. AWUOZS, Kalita, fot. Solecki, „Kościół św. Mikołaja”.

28 Np. widok Wolina według Lubinusa, 1617 r.; zdjęcia archiwalne z końca XIX i I połowy XX w.

29 AWUOZS, teczka Kościół pw. św. Mikołaja w Wolinie, Projekt koncepcyjny odbudowy - część ogólna, s. 11. 
wnętrza. Drugim bardzo ważnym warunkiem, od którego spełnienia zależała realizacja przedsięwzięcia, było zabezpieczenie wieży i ściany wschodniej zagrożonych postępującą destrukcją z powodu stałego nierównomiernego osadzania się części murów. Za oczywiste i logiczne uznano zachowanie dawnego obrysu obiektu - z trzema nawami rozdzielonymi filarami (proporcja szerokości nawy głównej do bocznych 2:1), ze ścianą wschodnią bez wydzielonego prezbiterium oraz wieżą zachodnią (il. 4). Inne założenie zaprzeczyłoby idei odbudowy na zasadzie rekonstrukcji - powstałaby zupełnie inna świątynia, niemająca cech wspólnych i organicznych powiązań z trzynastowieczną budowlą zawierającą w swojej strukturze kolejne etapy przemian będących świadectwem jej historii. Projekt koncepcyjny uwzględniał też zamiar przywrócenia budowli, z jej wysokim dachem i wyróżniającą się wieżą, pozycji dominanty w widoku miasta ${ }^{30}$.

Te założenia legły $\mathrm{u}$ podstaw opracowania trzech równoprawnych wariantów odbudowy. Wydaje się, że jeden z nich - w którym istniejąca struktura zyskałaby uzupełnienia wyraźnie współczesne, nieskontrastowane z dawnymi partiami - od początku nie wpisywał się w model przyjęty w naszym kraju przy odbudowie obiektów zabytkowych zniszczonych w czasie wojny ${ }^{31}$. Dwa pozostałe warianty, na które położono nacisk, sporządzone z poszanowaniem substancji o historycznym znaczeniu, prezentowały rozwiązania najbardziej dla niej korzystne - odbudowy na zasadzie rekonstrukcji. Pierwszy zakładał, że odbudowa powinna być pełną rekonstrukcją stanu budowli sprzed zniszczeń w 1945 roku, czyli uwzględniać dziewiętnastowieczne przeróbki będące świadectwem historycznych przemian, płaski strop, barokizujący hełm wieży oraz szczyt wschodni ukształtowane według ikonografii i inwentaryzacji zamieszczonej w publikacji H. Lemckego ${ }^{32}$. W tym wariancie zostałyby pominięte empory wzdłuż naw bocznych. Drugie rozwiązanie przewidywało rekonstrukcję opartą na hipotetycznych założeniach - z trzynawowym, pięcioprzęsłowym układem pseudobazylikowym odtworzonym na podstawie zachowanych śladów, z otwartym w pełnej wysokości prześwitem

30 AWUOZS, teczka Kościół pw. św. Mikołaja w Wolinie, s. 11-12. Zdaniem projektantów należało także chronić detal architektoniczny (służki, kształtki, profilowanie, odsadzki, gzymsy) oraz zachowane ślady dawnego wystroju obiektu, szczególnie w obrębie starszych faz, głównie na zewnętrznej i wewnętrznej ścianie wschodniej oraz wieży.

31 AWUOZS, teczka Kościół pw. św. Mikołaja w Wolinie, s. 13.

32 Hugo Lemcke, Die Bau- und Kunstdenkmäler des Regierungsbezirks Stettin, z. 4 Der Kreis Usedom - Wollin (Stettin: Kommissionsverlag von Leon Saunier, 1900). 
do wnętrza wieży i dwoma oknami od strony wschodniej oraz uzasadnionymi stylistycznie uzupełnieniami detalu ${ }^{33}$.

Zawarte w projekcie koncepcyjnym odbudowy wytyczne konserwatorskie zostały zaakceptowane przez mgr. inż. arch. Jana Wiesława Nowaka, Wojewódzkiego Konserwatora Zabytków w Szczecinie ${ }^{34}$. Wkrótce przedstawiono „Projekt koncepcyjny odbudowy - część szczegółową" ${ }^{5}$. Punktem wyjścia stała się pełna adaptacja zachowanej partii murów, północnego ciągu filarów międzynawowych i wieży oraz rekonstrukcja brakujących elementów i ubytków według stanu z XIX wieku - jedynej w pełni czytelnej historycznej formy świątyni w chwili podjęcia decyzji o jej odbudowie ${ }^{36}$. Projekt zakładał zrekonstruowanie rozebranej na początku lat siedemdziesiątych partii południowo-zachodniej ściany nawy bocznej o formach neogotyckich ${ }^{37}$, barokizującego hełmu wieży oraz wschodniego szczytu według materiałów ikonograficznych. Wnętrze zaprojektowano - również według zasady rekonstrukcji - zgodnie ze stanem z XIX stulecia. Zamierzano odtworzyć w układzie symetrycznym południowy ciąg filarów, a korpus nawowy przykryć stropem żelbetowym, płytowo-żebrowym, na zachowanej wysokości w systemie halowego układu naw ${ }^{38}$. Założenie, że dwa wschodnie przęsła naw północnej i południowej przeznaczone będą na zakrystię oraz kaplicę, pozwoliło projektantom zaaranżować w nawie głównej dwuprzęsłowe podwyższone prezbiterium ${ }^{39}$. W nawach północnej i południowej przewidziano empory o konstrukcji stalowo-drewnianej, z prowadzącymi na nie schodami wprost z naw bocznych oraz z wieży. Arkadę znajdującą się w ścianie oddzielającej prezbiterium od wieży, wcześniej przemurowaną, zaplanowano otworzyć w pełnej wysokości. Na podstawie zachowanych fragmentów zaprojektowano podziały okien

33 AWUOZS, teczka Kościół pw. św. Mikołaja w Wolinie, Projekt koncepcyjny odbudowy - część ogólna, s. 12.

34 AWUOZS, teczka Kościół pw. św. Mikołaja w Wolinie, s. 1.

35 AWUOZS, teczka Kościół pw. św. Mikołaja w Wolinie, Projekt koncepcyjny odbudowy - część szczegółowa („Parafia Rzymsko-Katolicka pw. św. Stanisława w Wolinie. Kościół pod wezwaniem św. Mikołaja w Wolinie, ul. Wojska Polskiego. Projekt koncepcyjny odbudowy. Zespół autorski: mgr inż. arch. Zbigniew Becker, mgr inż. arch. Irena Kukla, inż. arch. Stefan Kwilecki, mgr Bogdana Kozińska pod kierunkiem: mgr. inż. arch. Janusza Nekanda-Trepki, Szczecin 1989, Koncepcja architektoniczna odbudowy kościoła św. Mikołaja w Wolinie”).

36 AWUOZS, teczka Kościół pw. św. Mikołaja w Wolinie, s. 1.

37 Forma neogotycka pochodziła z generalnej przebudowy świątyni w $1857 \mathrm{r}$. Zob. Lemcke, Die Bau- und Kunstdenkmäler, 412-413.

38 AWUOZS, teczka Kościół pw. św. Mikołaja w Wolinie, Projekt koncepcyjny odbudowy - część szczegółowa, s. 1.

39 AWUOZS, teczka Kościół pw. św. Mikołaja w Wolinie, s. 2. 
w nawach bocznych. Okna w ścianie wschodniej miały nawiązywać do istniejących zachowanych form, z odtworzeniem centralnych okien w pełnej wyso-

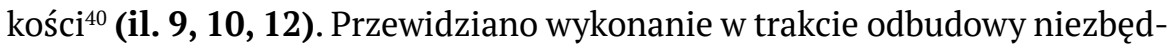
nych napraw i uzupełnień w istniejących ścianach zewnętrznych korpusu nawowego oraz odtworzenie kamiennych cokołów i brakujących fragmentów murów w fakturze cegły licowej. W odniesieniu do elewacji wieży pojawiło się rozwiązanie nawiązujące również do zachowanych form - w tym wypadku tynku. Zdecydowano także o tradycyjnej konstrukcji dachu i hełmu wieży ${ }^{41}$. Zgodnie z wymogami konserwatorskimi na pokrycie dachu nad korpusem nawowym zaproponowano materiał ceramiczny. Pokrycie hełmu wieży, opierzenia, rynny i rury spustowe zaplanowano wykonać z blachy cynkowej. Jeżeli chodzi o wnętrza, na ścianach wieży, zakrystii oraz kruchty przewidziano tynki, pozostałe ściany miały pozostać w fakturze cegły ${ }^{42}$.

W grudniu 1989 roku Konserwator Wojewódzki w Szczecinie zatwierdził projekt, wprowadzając pewne uwagi. Generalną zasadą, jaką według konserwatora należało przyjąć przy odbudowie zabytku, była „rekonstrukcja bryły kościoła według stanu sprzed 1945 roku”33. Konserwator Wojewódzki uważał, że należy poprawić sylwetę świątyni opracowując, jako alternatywną propozycję, rozwiązanie bardziej wysmukłej wieży i hełmu z zastosowaniem współczesnego detalu. Według niego zespół projektantów powinien znaleźć możliwość wykreowania współczesnego wnętrza z wprowadzeniem zachowanych elementów wyposażenia ${ }^{44}$. Konserwator zaproponował także podniesienie stropu w nawie głównej oraz zastosowanie empor tylko w części kościoła ${ }^{45}$.

Ostatecznie Konserwator Wojewódzki w Szczecinie arch. Jan Wiesław Nowak 26 czerwca 1990 roku zatwierdził projekt szczegółowy, po złożeniu przez głównego projektanta arch. Janusza Nekanda-Trepkę niezbędnej dokumentacji techniczno-architektonicznej odbudowy kościoła pw. św. Mikołaja ${ }^{46}$.

40 AWUOZS, teczka Kościół pw. św. Mikołaja w Wolinie, s. 2.

${ }^{41}$ AWUOZS, teczka Kościół pw. św. Mikołaja w Wolinie, s. 2.

42 AWUOZS, teczka Kościół pw. św. Mikołaja w Wolinie, s. 3.

43 AWUOZS, sygn. 1202, Urząd Wojewódzki Wydział Kultury i Sztuki, Wojewódzki Konserwator Zabytków, Szczecin, 1989.12.05, Kl. 3/5349/216/89, Sz. Pan arch. Janusz Nekanda-Trepka.

44 AWUOZS, sygn. 1202. Nie było wówczas wiadomo o jakichkolwiek zachowanych elementach wyposażenia, natomiast wcześniej dochodziło do kradzieży, m.in. skradziono dzwony pochodzące z wieży kościoła.

45 AWUOZS, sygn. 1202, Kl. 3/5249/216/89.

46 AWUOZS, sygn. 1201, Janusz Nekanda-Trepka [...] Szczecin 6.06.1990, Wojewódzki Konserwator Zabytków, Urząd Wojewódzki w Szczecinie. Zespół projektowy: mgr inż. arch. Irena Kukla, mgr inż. arch. Zbigniew Becker, mgr inż. Maria Łada-Zabłocka (konstrukcja), mgr inż. 
Po zatwierdzeniu końcowego projektu oraz uzyskaniu decyzji lokalizacyjnej w 1990 roku $^{47}$ przygotowano harmonogram robót. Rozpoczęto je w 1991 roku od stabilizacji wieży - palowania strefy nacisku i założenia rusztu na poziomie posadzki ${ }^{48}$. Należy przypuszczać, że podobne czynności wykonano przy ścianie wschodniej oraz filarach ${ }^{49}$. Do właściwej odbudowy przystąpiono w 1993 roku. Wzmocniono fundamenty ściany południowej oraz zrekonstruowano narożnik południowo-zachodni ${ }^{50}$. Od roku 1994 prowadzono dalsze prace konstrukcyjne oraz rekonstrukcyjne i wykończeniowe ${ }^{51}$.

Na spotkaniu Konserwatora Wojewódzkiego mgr Ewy Staneckiej, Konserwatora Diecezjalnego ks. mgr. Romana Kostynowicza i głównego projektanta odbudowy arch. Janusza Nakanda-Trepki w Wolinie 16 lutego 1998 roku omówiono poziom zaawansowania prac przy odbudowie świątyni. Montaż konstrukcji drewnianej wieży wykonano w pierwszej połowie roku 1997; hełm wieży ustawiono 21 sierpnia 1997 roku; do krycia hełmu zastosowano blachę miedzianą - prace ukończono w grudniu 1997 roku; dach hali świątyni pokryto dachówką ceramiczną - prace ukończono w grudniu 1996 roku; wykonano okna, ale bez szklenia; zastały ukończone portale, jednak bez drzwi; posadzki zamierzano przykryć płytkami klinkierowymi; położono strop. Na spotkaniu ustalono, że w wieży kościoła zostaną wstawione okna z żaluzjami, natomiast w latarni okna widokowe ${ }^{52}$. Planowano rozebrać ścianę pod emporą w drugim przęśle między nawą główną i południową; w ten sposób udałoby się powiększyć prezbiterium ${ }^{53}$.

Feliks Kochański (instalacje elektryczne), mgr inż. Maria Nekanda-Trepka (instalacje sanitarne). Zob. http://www.parafiawolin. pl/index.php/sample-sites/parafia/koscioly/kolegiata-pw-sw-mikolaja-biskupa/odbudowa (dostęp 22 marca 2016).

47 AKDSK, teczka Dekanat Wolin, Sprawozdanie z przekazania i odbioru obiektu sakralnego.

48 Prace zaprojektował i wykonał inż. Karol Klaus z Gliwic. Zob. www.parafiawolin.pl (dostęp 22 marca 2016). AWUOZS, Karta Ewidencji Zabytków Architektury i Budownictwa (dalej: KEZAiB), Cezary Nowakowski, „Rzymsko-katolicki kościół parafialny pw. św. Mikołaja, Wolin”, Szczecin 1999.

49 AWUOZS, teczka Kościół pw. św. Mikołaja w Wolinie, Projekt koncepcyjny odbudowy - część ogólna.

50 Prace wykonała firma „System” ze Świnoujścia pod kierownictwem Antoniego Stryczyńskiego. Zob. AWUOZS, KEZAiB, Nowakowski, „Rzymsko-katolicki kościół”.

51 Prace wykonała firma budowlana z Kamienia Pomorskiego, którą kierował Mieczysław Kwiatkowski, oraz firma PPPUH „PUH” z Gorzowa Wielkopolskiego. Zob. AWUOZS, KEZAiB, Nowakowski, „Rzymsko-katolicki kościół”.

52 AKDSK, teczka Dekanat Wolin, Wolin, 18.02.1998. Wyjazd z WKZ p. Ewa Stanecka, p. Nekanda-Trepka do Wolina w sprawie odbudowy kościoła św. Mikołaja.

53 AKDSK, teczka Dekanat Wolin, Wolin, 18.02.1998. 
Prace przy odbudowie zakończono najprawdopodobniej u schyłku 1999 roku $^{54}$. Długo zastanawiano się nad wyborem odpowiedniego rozwiązania dla wieży. Mimo przyjęcia dla całości przedsięwzięcia koncepcji „rekonstrukcji formy przedwojennej z ideą formy zewnętrznej” - bryły w formach neogotyckich z cegły licowej, wieży tynkowanej z uzupełnieniem gzymsów betonowych z końca XIX wieku i barokizującym hełmem ${ }^{55}$ - uzasadnianej dodatkowo znacznymi uszkodzeniami lica cegieł trzonu wieży, konserwator diecezjalny uważał, że należy pozostać przy wieży w cegle, naprawiając tylko uszkodzenia ${ }^{56}$. Janusz Nekanda-Trepka był przeciwny przywróceniu ceglanej licowej faktury wieży; jak uzasadniał, „naprawa uszkodzeń wymagałaby przelicowania tak dużych partii lica, że trudno byłoby nazwać go autentycznym, a uczytelnienie nawarstwień historycznych i próby rekonstrukcji nieznanego w formie detalu gzymsowego (obecnie są to ciągnione gzymsy tynkowe o prawie modernistycznym wykroju) musiałoby doprowadzić do powstania preparatu konserwatorskiego. Ponadto utraciłoby się ponadstuletni obraz budowli, który według założeń musi być przywrócony" ${ }^{57}$. Ostatecznie usunięto tynki ze ścian zewnętrznych wieży do drugiej kondygnacji i przelicowano części lica cegieł, pozostawiając płytsze uszkodzenia po zachodniej stronie elewacji (il. 17, 18).

Archidiecezjalna Komisja ds. Sztuki Kościelnej dokonała odbioru prac wykonanych przy odbudowie kościoła pw. św. Mikołaja w Wolinie 2 października $2000 \mathrm{roku}^{58}$. Uroczyste poświęcenie świątyni odbyło się już 15 października ${ }^{59}$.

54 Zob. www.parafiawolin.pl (dostęp 22 marca 2016). Termin zakończenia prac 30.06.2000. Zob. AKDSK, teczka Dekanat Wolin, Sprawozdanie z przekazania i odbioru obiektu sakralnego.

55 Była to czytelna kompozycja odcinająca dwie odrębne bryły i scalona detalem pochodzącym z tego samego okresu. Zob. AKDSK, teczka Dekanat Wolin, Szczecin 26.07.1997, Jego Wielebność Ksiądz Infułat Roman Kostynowicz Diecezjalny Konserwator Zabytków.

56 AKDSK, teczka Dekanat Wolin, Szczecin 26.07.1997, Jego Wielebność Ksiądz Infułat Roman Kostynowicz Diecezjalny Konserwator Zabytków.

57 AKDSK, teczka Dekanat Wolin, Szczecin 26.07.1997, Jego Wielebność Ksiądz Infułat Roman Kostynowicz Diecezjalny Konserwator Zabytków. Zaproponowano „pobiałę” wapienną o grubości ok. 5 mm stosowaną na Pomorzu w średniowieczu, nagminnie usuwaną w XIX w. w trakcie tzw. regotyzacji.

58 AKDSK, teczka Dekanat Wolin, Sprawozdanie z przekazania i odbioru obiektu sakralnego.

59 Zob. Marek Cześnin i Maria Kompowska, „Wolin, parafia pw. św. Mikołaja Biskupa”, w Schematyzm archidiecezji szczecińsko-kamieńskiej", red. Edmund Cybulski, Teresa Dokładna i Anita Gawęda (Szczecin: Kadruk, 2007), 542. W KEZAiB odnotowano: „15.10.2000 - zakończenie odbudowy i rekonsekracja świątyni”. Jest to zapewne pomyłka. Zob. AWUOZS, KEZAiB, Nowakowski, „Rzymsko-katolicki kościół”. 
Według autora opracowania, zrealizowanie przyjętej koncepcji odbudowy na zasadzie rekonstrukcji stanu kościoła sprzed zniszczeń w 1945 roku (il. 1), z uwzględnieniem zmian przy przebudowie z drugiej połowy XIX wieku i z dodaniem kilku rozwiązań - zresztą uzasadnionych - z drugiego wariantu odbudowy rekonstrukcyjnej, przyniosło oczekiwany efekt w postaci równowagi między fazami będącymi świadectwem historii obiektu. Udało się utrzymać formę kościoła o trzech rozdzielonych filarami nawach. Zachowana partia murów, filary oraz wieża umożliwiły wykonanie pełnej adaptacji dawnej substancji. Niezbędne naprawy i uzupełnienia w istniejących ścianach zewnętrznych, odtworzenie kamiennego cokołu oraz odbudowa rozebranego fragmentu ściany południowo-zachodniej w fakturze cegły licowej były istotne ze względu na ostatnią przebudowę z końca XIX wieku (il. 5, 6, 15, 16). Wydaje się jednak, że cegła wykorzystana do realizacji tych prac mogłaby być dobrana zdecydowanie staranniej. Ścianę wschodnią zwieńczono szczytem zakończonym pseudosygnaturką (il. 13, 14). Co prawda takie rozwiązanie zastosowano w trakcie ostatniej przebudowy w XIX wieku, jednak w materiałach ikonograficznych począwszy od roku 1915 widoczny jest w tym miejscu szczyt według projektu Lemckego z 1898 roku, z wyróżniającymi się dwiema centralnie umieszczonymi sterczynami ${ }^{60}$ (il. 1, 11). Wojewódzki Konserwator Zabytków ze Szczecina zaproponował, jako alternatywne rozwiązanie, wieżę i hełm bardziej wysmukłe, wykonane we współczesnym materiale i detalu. Tylko na rycinie Lubinusa z 1618 roku można dostrzec smukły, wysoki hełm wieży. Najprawdopodobniej w trakcie odbudowy po pożarze w 1628 roku zdecydowano o niższym hemie; od tego momentu nad miastem górowała wieża kościoła pw. św. Jerzego. Po olbrzymich zniszczeniach Wolina w czasie ostatniej wojny, rozbiórce ruiny kościoła św. Jerzego i przy stosunkowo niskiej współczesnej zabudowie, zrealizowana koncepcja odbudowy świątyni, $\mathrm{z}$ wyeksponowaniem wieży, dała pożądany efekt budowli dominującej w panoramie miasta. Wydaje się, że zastosowane rozwiązanie - barokizujący hełm - jest jak najbardziej trafne, tym bardziej że nawiązuje do stanu sprzed 1945 roku. We wnętrzu świątyni umieszczono empory w nawach bocznych na długości czterech przęseł. Urządzenie kaplicy oraz zakrystii w nawach bocznych w linii drugiego przęsła umożliwiło powiększenie prezbiterium i podniesienie jego poziomu o trzy stopnie w porównaniu z poziomem posadzki świątyni

60 Szczyt ściany wschodniej kościoła św. Mikołaja z 1898 r. Za: Lemcke, Die Bau- und Kunstdenkmäler, il. 43. Zob. np. Fotopolska.eu. 
(il. 10). W wyniku rekonstrukcji centralnych otworów okiennych prezbiterium w ich pełnej wysokości podwyższono strop nawy głównej - w ten sposób wypełniono wytyczne konserwatora wojewódzkiego. Generalnie dzięki przyjętej koncepcji przestrzeń świątyni jest bardziej czytelna i nawiązuje do zróżnicowanego poziomu sklepień nawy głównej i bocznych, które zostały zlikwidowane podczas odbudowy po pożarze w 1628 roku $^{61}$. Należy dodać, że otwarcie w pełnej wysokości arkady w ścianie oddzielającej prezbiterium od wieży, wcześniej przemurowanej, dało wrażenie lekkości wieży od strony prezbiterium (il. 7, 8).

Odbudowa zabytkowej architektury w Polsce po drugiej wojnie światowej jest tematem wielu opracowań ${ }^{62}$. Jako pewien fenomen była i jest dyskusyjnym zagadnieniem. Wobec ogromnych zniszczeń spowodowanych wojną, dziewiętnastowieczne podejście do zabytku okazało się niewystarczające. Wcześniejsze stanowisko: należy zachowywać dawną architekturę przez doraźną pielęgnację, naprawy i remonty ${ }^{63}$, podtrzymywać trwanie zabytku w zastanym stanie ${ }^{64}$, nie dopuszczać do restauracji ${ }^{65}$, w wyjątkowych przypadkach restaurować spełniając ściśle określone warunki ${ }^{66}$ - sprawdzało się w „zwykłych czasach”, kiedy pamiątek przeszłości nie rujnowały nagłe zdarzenia i kataklizmy ani niszczycielskie działania wojenne. Już po pierwszej wojnie światowej dawne kierunki myśli konserwatorskiej nie wytrzymywały

${ }^{61}$ AWUOZS, teczka Kościół pw. św. Mikołaja w Wolinie, Projekt koncepcyjny odbudowy - część ogólna, s. 6: „W trakcie odbudowy zlikwidowano sklepienia obniżając filary i wprowadzając strop płaski, zmieniono ścianę arkadową nad filarami”.

62 Np. Tadeusz Kowalski, Rekonstrukcja zabytków architektury. Teoria a praktyka (Warszawa: Wydawnictwo PKZ, 1985); Bogusław Szmygin, Kształtowanie koncepcji zabytku i doktryny konserwatorskiej w Polsce w XX wieku (Lublin: Wydawnictwo Politechniki Lubelskiej, 2000); Marek Barański, „Odbudowane Stare Miasto i zabytki Warszawy w ocenie zagranicznych konserwatorów”, Wiadomości Konserwatorskie 13 (2003): 55-61; Bohdan Rymaszewski, Polska ochrona zabytków (Warszawa: Wydawnictwo Naukowe Scholar, 2005).

63 Zob. Janusz Krawczyk, „Historia i teraźniejszość teorii konserwacji”, w Problemy konserwacji i badań zabytków architektury, red. Aleksandra Kociołkowska (Studzienka: Europejska Fundacja Ochrony Zabytków, 2007), 15-32.

64 Zob. Georg Dehio, „Ochrona zabytków i opieka nad zabytkami w XIX stuleciu (1905)”, w Zabytek $i$ historia, red. Jarosław Krawczyk (Warszawa: Oficyna Wydawnicza „Mówią wieki”, 2007), 203-215; Alois Riegl, „Nowoczesny kult zabytków. Jego istota i powstanie (1903)”, w Zabytek, 191-202.

65 Zob. Marian Arszyński, Idea - pamięć - troska. Rola zabytków w przestrzeni społecznej i formy działań na rzecz ich zachowania od starożytności do połowy XX wieku (Malbork: Muzeum Zamkowe, 2007), 107-109.

${ }^{66}$ Eugene Viollet-le-Duc, „Słownik logiczny architektury francuskiej od XI do XVI wieku (1854-1868)", w Zabytek, 75-88. 
zderzenia z przekonaniem, że nie powinno się zachowywać ruin wojennych ${ }^{67}$. Po drugiej wojnie światowej odbudowa (rekonstrukcja) zabytków stała się doniosłą sprawą. Walter Frodl przyznając, że odbudowa zniszczonych zabytków, ze względu na ich znaczenie, spowodowała zatracenie „wielu spośród tych pięknych reguł, które były dla nas tak oczywiste”"68, jednocześnie usprawiedliwiał ją wskazując na konieczność chwili69.

U podstaw długoletniej batalii Kościoła katolickiego o odzyskanie świątyni w Wolinie legła również historia budowli, mająca swój początek w XIII wieku. Należy pamiętać, że utworzenie pierwszego biskupstwa pomorskiego ze stolicą w Wolinie było ściśle związane z polityką władców polskich tamtego okresu. Współcześnie, w opinii wielu środowisk i instytucji, odbudowa takich obiektów jak kościół pw. św. Mikołaja w Wolinie potwierdza odwieczną obecność Kościoła katolickiego i Polski na tych terenach. Świadczy o wiernych i społeczeństwie, ale także o świadomości władz państwowych i kościelnych co do wartości dźwiganych z ruin budowli sakralnych.

Granitowe i ceglane kościoły trwale zrośnięte z krajobrazem Pomorza Zachodniego, wznoszone przez stulecia, są świadectwem wkładu Pomorzan w kulturowy rozwój tej części Europy ${ }^{70}$. Między innymi czynniki społeczne i polityczne oraz ekonomiczne i kulturalne wpłynęły na poziom artystycznego dorobku regionu, w tym także architektury sakralnej. W Polsce znaczną część zabytków nieruchomych stanowią budowle sakralne, przez kilkadziesiąt lat po drugiej wojnie światowej traktowane przez władze państwowe w niewłaściwy sposób. Szczególnie widoczne było to na Ziemiach Zachodnich i Północnych. Stanowisko administracji, w szczególności Urzędu do Spraw Wyznań, długo stało na przeszkodzie w odbudowie zabytkowych świątyń. Również służby konserwatorskie pod naciskiem władz państwowych i par-

67 Szmygin, Kształtowanie koncepcji, 61. Zob. też Józef Piotrowski, Ochrona zabytków a odbudowa kraju (Lwów: Gubrynowicz i Syn, 1916).

68 Walter Frodl, „Pojęcie i kryteria wartościowania zabytków”, tłum. Marian Arszyński, Biblioteka Muzeów i Ochrony Zabytków seria B 13 (1966): 32.

69 Frodl, „Pojęcie”, 34.

70 Zob. Gwido Chmarzyński, „Tam, gdzie przodowało budownictwo zakonne”, w Pomorze Zachodnie, red. Janusz Deresiewicz, t. 2, cz. 1 (Poznań: Instytut Zachodni, 1949), 485-514; Zygmunt Świechowski, „W krainie hal i bazylik”, w Pomorze, 331-353; Szczęsny Skibiński, „Pomorze Zachodnie i Nowa Marchia”, w Dzieje sztuki polskiej, red. Teresa Mroczko i Marian Arszyński, t. 2 (Warszawa: IS PAN, 1995), 111-123; Zygmunt Świechowski, Architektura romańska w Polsce (Warszawa: DiG, 2000), 15, 26. 
tyjnych, ale także przez swoje działania, nie do końca wypełniły powierzoną misję. Niektóre z ruin, w tym kościoła pw. św. Mikołaja w Wolinie, udało się przywrócić do życia dopiero na przełomie wieków (il. 19).

\section{Bibliografia}

\section{Materiały archiwalne}

Archiwum Diecezji Zielonogórsko-Gorzowskiej w Zielonej Górze (ADZG): sygn. 1093, Korespondencja z władzami świeckimi 1963-1972.

Archiwum Konserwatora Diecezji Szczecińsko-Kamieńskiej w Szczecinie (AKDSK): teczki: Rozmowy 19 XI 1973 r. w UdSW, Wojewody Szcz. 22 XII 1973; Art. 1, Art. 2+sprawy dodatkowe, Art. 2. II kwestionariusz, Art. 2. III kwestionariusz; Ruiny 1985; Ruiny kościołów, pisma U/Wyznań w sprawie ruin; Dekanat Wolin par. pw. św. Stanisława B.M. Wolin; Obiekt - ruina obiektu sakralnego, Miejscowość - Wolin, województwo - szczecińskie.

Archiwum Wojewódzkiego Urzędu Ochrony Zabytków w Szczecinie (AWUOZS): sygn.: II/41; II/210; II/243; 1201; 1202. Teczki: Karta Obiektu Zabytkowego, Kościół pw. św. Mikołaja Wolin, 1959; Maria Bujwid, „Kościół św. Mikołaja. Kosztorys - wstępna wycena”. PP PKZ, Szczecin 1972; Kazimiera Kalita, fot. Grzegorz Solecki, „Kościół św. Mikołaja w Wolinie. Dokumentacja historyczno-architektoniczna”. PP PKZ, Szczecin 1973; Tadeusz Zajączkowski, „Kościół św. Mikołaja. Projekt ramy zabezpieczającej”. PP PKZ, Szczecin 1973; Kościół pw. św. Mikołaja w Wolinie. Projekt koncepcyjny odbudowy - część ogólna; Kościół pw. św. Mikołaja w Wolinie. Projekt koncepcyjny odbudowy - część szczegółowa; Cezary Nowakowski, „Rzymskokatolicki kościół parafialny pw. św. Mikołaja. Wolin”, Karta Ewidencji Zabytków Architektury i Budownictwa, Szczecin 1999, WUOZS.

Instytut Pamięci Narodowej: sygn. 048/1.

\section{Druki i opracowania}

Arszyński, Marian. Idea - pamięć - troska. Rola zabytków w przestrzeni społecznej i formy działań na rzecz ich zachowania od starożytności do połowy XX wieku. Malbork: Muzeum Zamkowe, 2007.

Barański, Marek. „Odbudowane Stare Miasto i zabytki Warszawy w ocenie zagranicznych konserwatorów”. Wiadomości Konserwatorskie 13 (2003): 55-61.

Bastowska, Krystyna. „Dzieje zabytkowych świątyń dawnego województwa koszalińskiego w latach 1945-1989”. W Społeczeństwo - państwo - Kościół (1945-1989). Materiały ogólnopolskiej konferencji naukowej, Szczecin, 15-16 VI 2000 r., red. Arkadiusz Kawecki, Krzysztof Kowalczyk i Artur Kubaj, 88-94. Szczecin: Stowarzyszenie Absolwentów US, 2000. 
Chmarzyński, Gwido. „Tam, gdzie przodowało budownictwo zakonne”. W Pomorze Zachodnie, red. Janusz Deresiewicz. T. 2, cz. 1, 485-514. Poznań: Instytut Zachodni, 1949.

Cześnin, Marek, i Maria Kompowska. „Wolin, parafia pw. św. Mikołaja Biskupa”. W Schematyzm archidiecezji szczecińsko-kamieńskiej”, red. Edmund Cybulski, Teresa Dokładna i Anita Gawęda, 541-542. Szczecin: Kadruk, 2007.

Dehio, Georg. „Ochrona zabytków i opieka nad zabytkami w XIX stuleciu (1905)”. W Zabytek $\mathrm{i}$ historia, red. Jarosław Krawczyk, 203-215. Warszawa: Oficyna Wydawnicza „Mówią wieki”, 2007.

Frodl, Walter. „Pojęcie i kryteria wartościowania zabytków”. Tłumaczenie Marian Arszyński. Biblioteka Muzeów i Ochrony Zabytków seria B 13 (1966).

Gierlasiński, Janusz. „Kościół św. Mikołaja w Wolinie. Losy budowli w latach 1945-1988”. Acta Universitatis Nicolai Copernici. Zabytkoznawstwo i Konserwatorstwo 46 (2015): 265-286.

Kalita, Kazimiera. „Historia i budowa kościoła św. Mikołaja w Wolinie”. Materiały Zachodniopomorskie 19 (1973): 445-477.

Kochanowska, Janina. „Losy zabytków sakralnych Pomorza Zachodniego podczas wojny i w pierwszych latach po wojnie”. W Wspólne dziedzictwo? Ze studiów nad stosunkiem do spuścizny kulturowej na Ziemiach Zachodnich, red. Zbigniew Mazur, 201-237. Poznań: Instytut Zachodni, 2000.

Kowalski, Tadeusz. Rekonstrukcja zabytków architektury. Teoria a praktyka. Warszawa: Wydawnictwo PKZ, 1985.

Kozłowski, Kazimierz. Źródła do dziejów Pomorza Zachodniego. T. 14. Szczecin: Uniwersytet Szczeciński, 2007.

Krawczyk, Janusz. „Historia i teraźniejszość teorii konserwacji”. W Problemy konserwacji i badań zabytków architektury, red. Aleksandra Kociołkowska, 15-32. Studzienka: Europejska Fundacja Ochrony Zabytków, 2007.

Lemcke, Hugo. Die Bau- und Kunstdenkmäler der Regierungsbezirks Stettin. Z. 4 Der Kreis Usedom - Wollin. Stettin: Kommissionsverlag von Leon Saunier, 1900.

Piotrowski, Józef. Ochrona zabytków a odbudowa kraju. Lwów: Gubrynowicz i Syn, 1916. Riegl, Alois. „Nowoczesny kult zabytków. Jego istota i powstanie (1903)”. W Zabytek i historia, red. Jarosław Krawczyk, 191-202. Warszawa: Oficyna Wydawnicza „Mówią wieki”, 2007.

Rymaszewski, Bohdan. Polska ochrona zabytków. Warszawa: Wydawnictwo Naukowe Scholar, 2005.

Skibiński, Szczęsny. „Pomorze Zachodnie i Nowa Marchia”. W Dzieje sztuki polskiej, red. Teresa Mroczko i Marian Arszyński. T. 2, 111-123. Warszawa: IS PAN, 1995.

Szmygin, Bogusław. Kształtowanie koncepcji zabytku i doktryny konserwatorskiej w Polsce wXX wieku. Lublin: Wydawnictwo Politechniki Lubelskiej, 2000.

Świechowski, Zygmunt. Architektura romańska w Polsce. Warszawa: DiG, 2000. 
Świechowski, Zygmunt. „W krainie hal i bazylik”. W Pomorze Zachodnie, red. Janusz Deresiewicz. T. 2, cz. 1, 331-353. Poznań: Instytut Zachodni, 1949.

Viollet-le-Duc, Eugene. „Słownik logiczny architektury francuskiej od XI do XVI wieku (1854-1868)". W Zabytek i historia, red. Jarosław Krawczyk, 75-88. Warszawa: Oficyna Wydawnicza „Mówią wieki”, 2007.

\section{Materiały internetowe}

www.parafiawolin.pl [22.03.2016]. www.pbi.edu.pl [23.06.2013], Polska Biblioteka Internetowa, Protokół nr 171, k. 89, Wytyczne stanowiska partii w sprawie stosunków między państwem a Kościołem. 


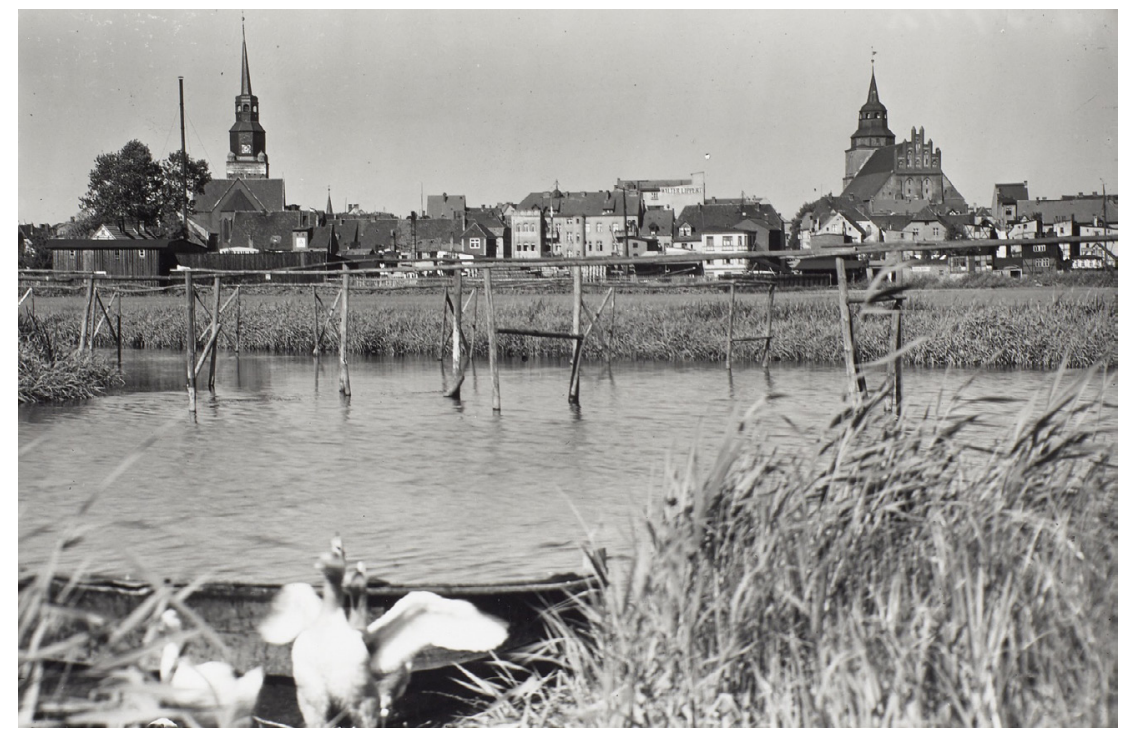

Il. 1. Panorama Wolina, 1934. Za: fotopolska.eu

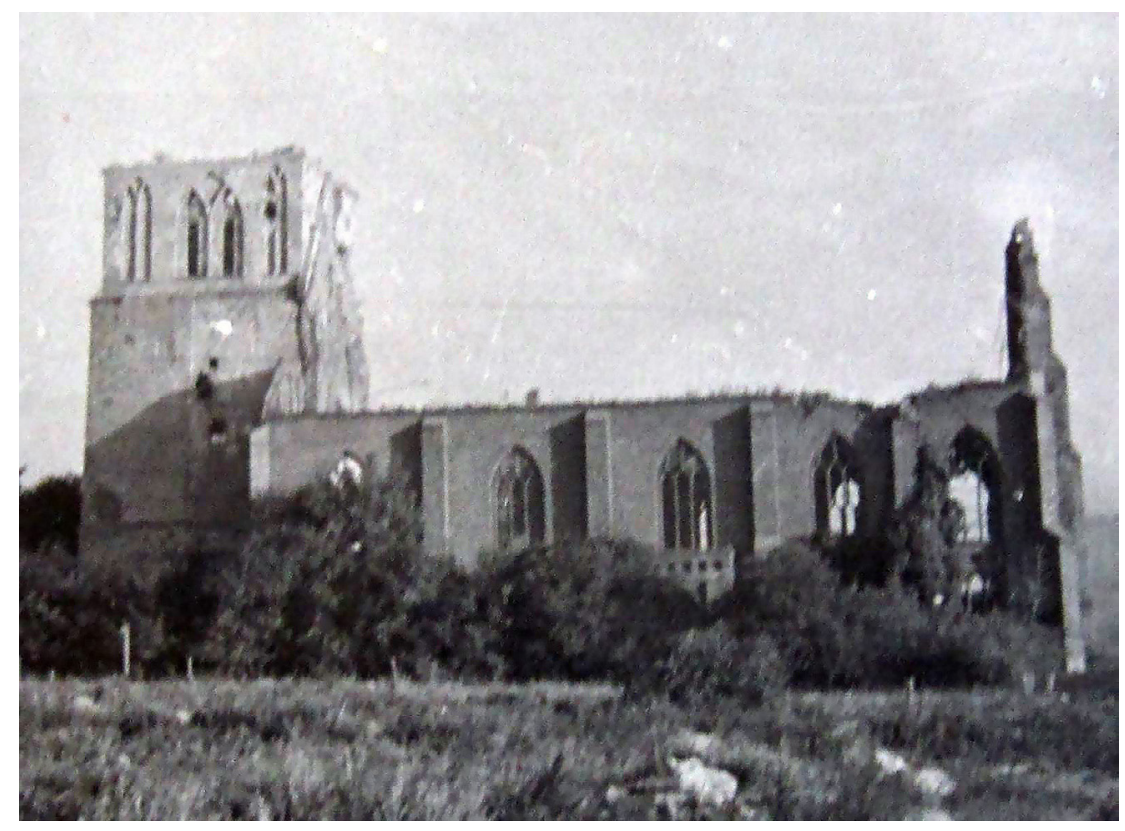

Il. 2. Wolin, kościół pw. św. Mikołaja, około 1959. Za: AWUOZS, KOZ, Kościół pw. św. Mikołaja, Wolin, 1959. 


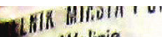

wo Wolinie

of azczecinskje: 0 2nak: $222 u-4 / 57$

wolin, $1907-09-10$

0 i c r $23 \mathrm{~A}$

(20 podstowic art.4 ust.3 pkt 2 , art.20, art.22 ust. 1 i 2 , art.25 art.35 ust.1,art. 45 ust.1 pkt 2 ustawy $z$ ánia 29 kwietnia $1985 \mathrm{r}$. - gospodarce gruntani 1 wywzaszczaniu nieruchonosc1 /0z.U. Nr 22, poz.99/, przopison J 2 ust.3, 310 ust.1.5 15, s 24, 525 rozporzadzenia kaćy hínistróu $z$ dnia 16 września 1985 r. w sprawie szczegózowych zasad 1 tryou oddawania $w$ użytkowanie wioczyste grunców 1 sprzedazy níoruchonoúci paristwowych, kosztów i rozliczeń z tym związanych orez zarzadzania sprzedanymi nieruchomościami/ Dz.U. Nr 47,poz, 239/ oraz na podstawic przepisón g 3 ust. 1 i $3,54,310$ rozporząózenia kady hinistrón z d́nia 16 wrześnla $1985 \mathrm{r}$. W sprawie zasad i trybu ustatania oplat z tytuiu užytkowania wieczystego,zarządu i użytkowam hia gruntów /0z.U. Ur 47, poz.241/,

$$
\text { o r z e k a m: }
$$

1. Uddae w użytkowanie wieczyste dziazkg Wr $55 / 100 . p o w .2562 \mathrm{n}^{2}$ na terenie miasta folina-obreb 3, na której polożare sa - wieża 1 mury Kosciola, zaoisanạ w Ksigdzo Vleczystoj Nr 12413 w Paristwowym biurze Notarialnym w Swinoujściu na rzecz Marafii św. standszava bi w holinie-reprezontowariej przez proboszcza ks. Jana Uberman.

- Uddac a uzytkowanie wieczyste dziazke na okres 99 lat, liczac od daty zawarcia aktu notarialnego z możliwoscia przedzuzenia umowy na dalszy okres.

uprzedac na wiasnob́c wieże $i$ mury Kościola znajdujace się na dziazco na rzecz Parafil sw. Staniszawa BH $w$ wolinie reprezentowanej przez probaszcza ks. Jana Uberman.

Ustalić wartośc sprzedawanych- wieży i murów Kościola na podstawlo szacunku sporzązonego przez biaglego z Iisty Urzędu. Wojowódzkiago ngr inż. Romualda Piątkowskiego w sposób następujacy:

- cena szacunkowa wieźy ... $\quad 1.670 .864 \mathrm{zz}$.

- cena szacunkowa murów koscioza _ _ $\ldots-1,470,848$ z ${ }_{2}$.

- cena zęczna wynosi

3.141 .71222

Przyznac nabywcy so, znizki cony sprzeciazy wiezy 1 nurów kosaioze. " zwlazku z czyn lączna cona po zhizce wynosi 1.570 .056 zz f

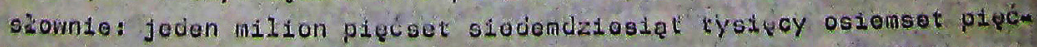

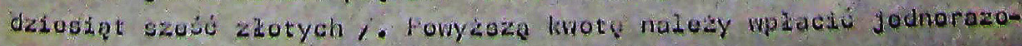
no najpózntej $w$ driu zawercio aktu notarialnogo.

$$
+1 .
$$

Il. 3. Decyzja G 8228-4/87. Źródło: AKDSK, teczka dekanat Wolin par. pw. św. Stanisława B.M., Wolin. (Fot. J. Gierlasiński) 


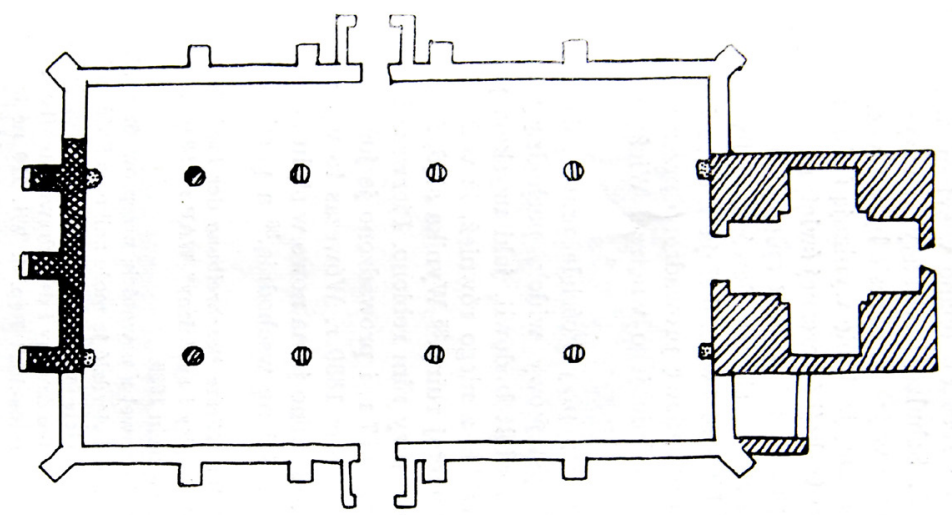

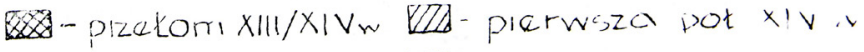

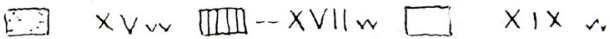

Il. 4. Wolin, kościół pw. św. Mikołaja. Rzut poziomy. (Za: K. Kalita, „Historia i budowa kościoła Św. Mikołaja w Wolinie”. Materiały Zachodniopomorskie, 19 (1973), il. 3)

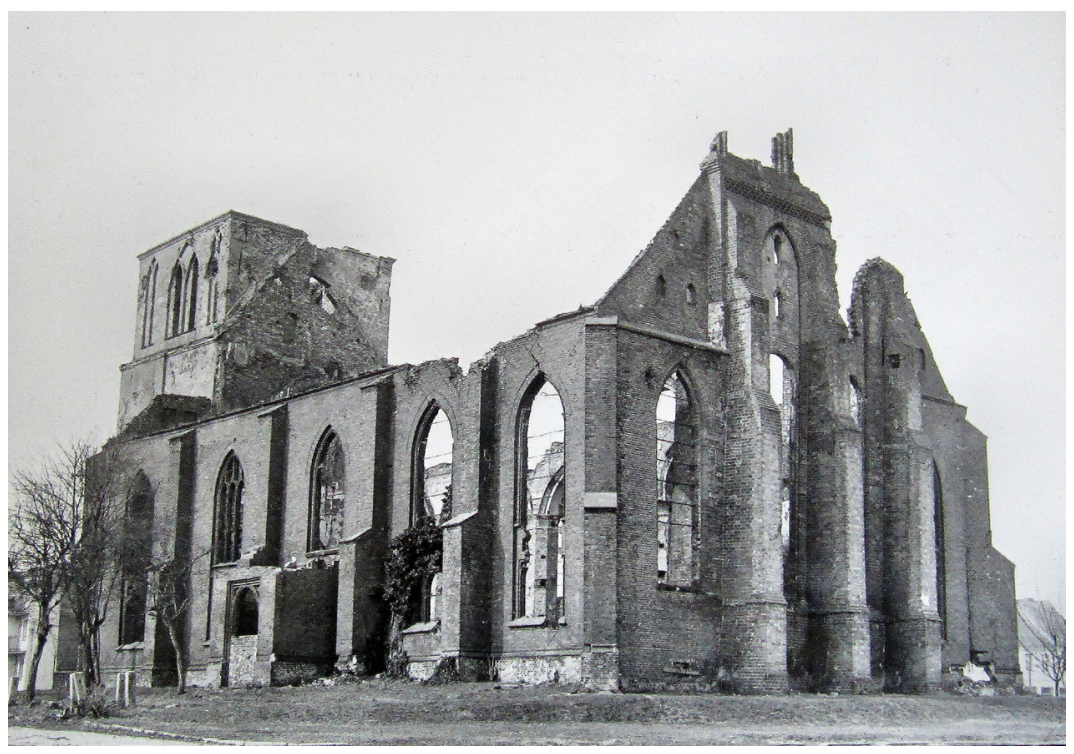

Il. 5. Wolin, kościół pw. św. Mikołaja. Widok bryły od strony południowo-wschodniej, około 1971. (Za: K. Kalita, fot. G. Solecki, „Kościół św. Mikołaja w Wolinie. Dokumentacja historyczno-architektoniczna”, Szczecin: PP PKZ, 1973, fot. 16. 


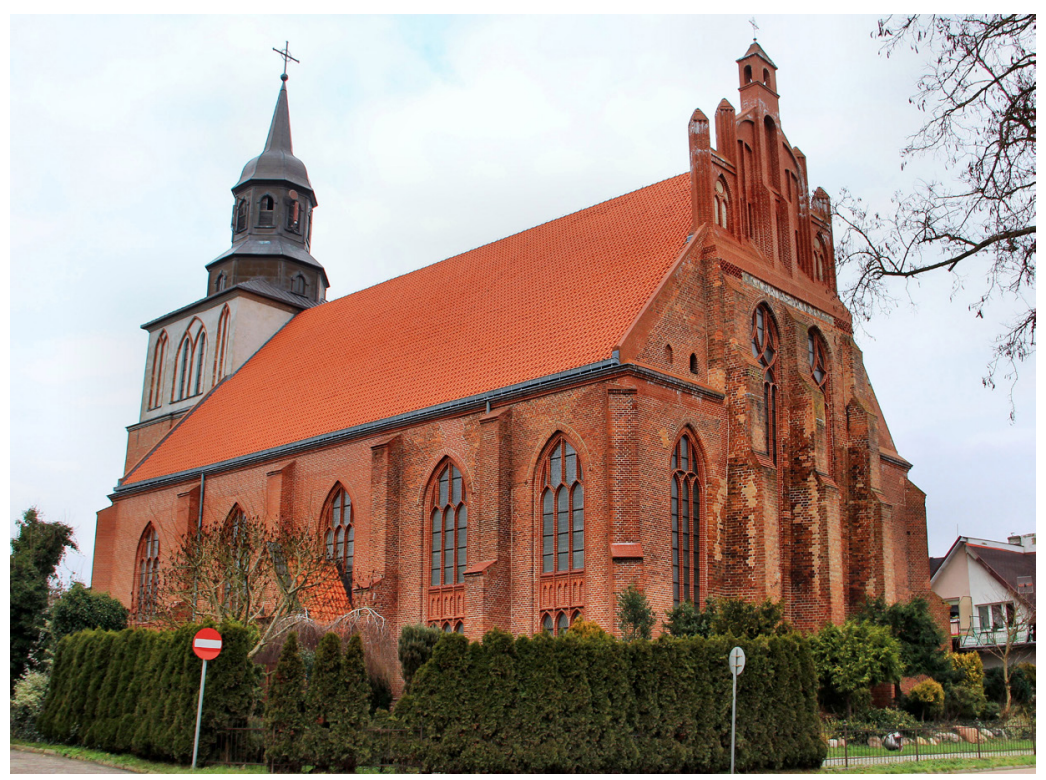

Il. 6. Wolin, kościół pw. św. Mikołaja. 2014. Fot. J. Gierlasiński

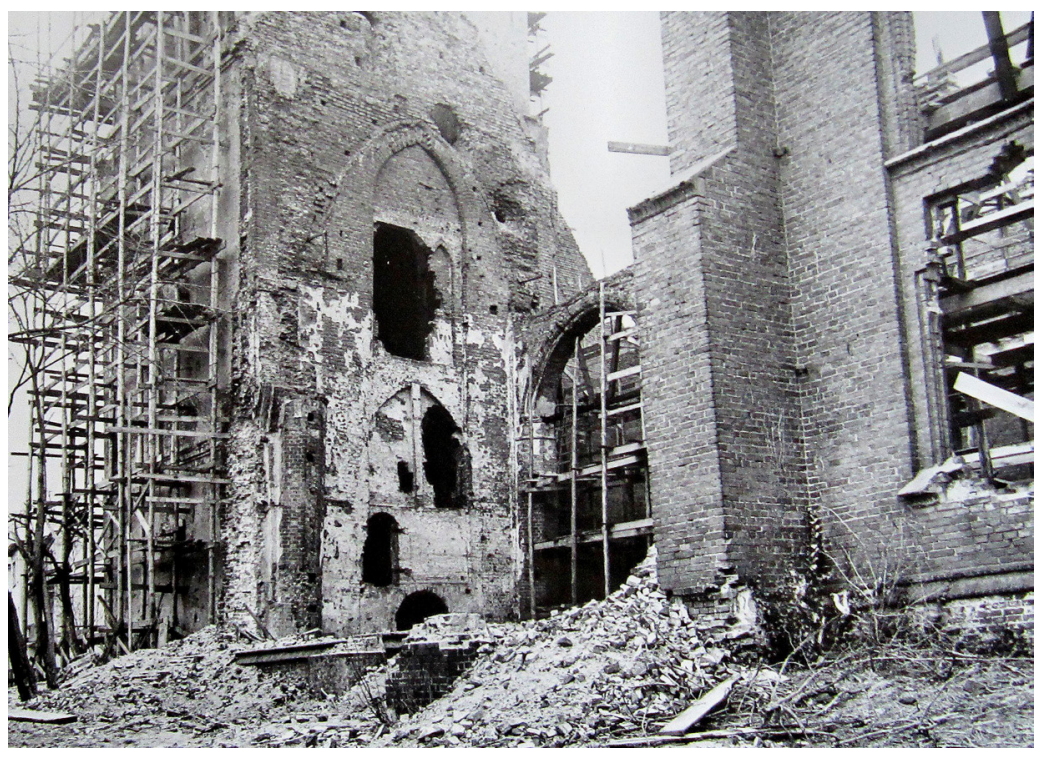

Il. 7. Wolin, kościół pw. św. Mikołaja. Widok wschodniej ściany wieży oraz częściowo rozebranej ściany południowej, około 1972. (Za: K. Kalita, fot. G. Solecki, „Kościół św. Mikołaja w Wolinie”, fot. 19. 


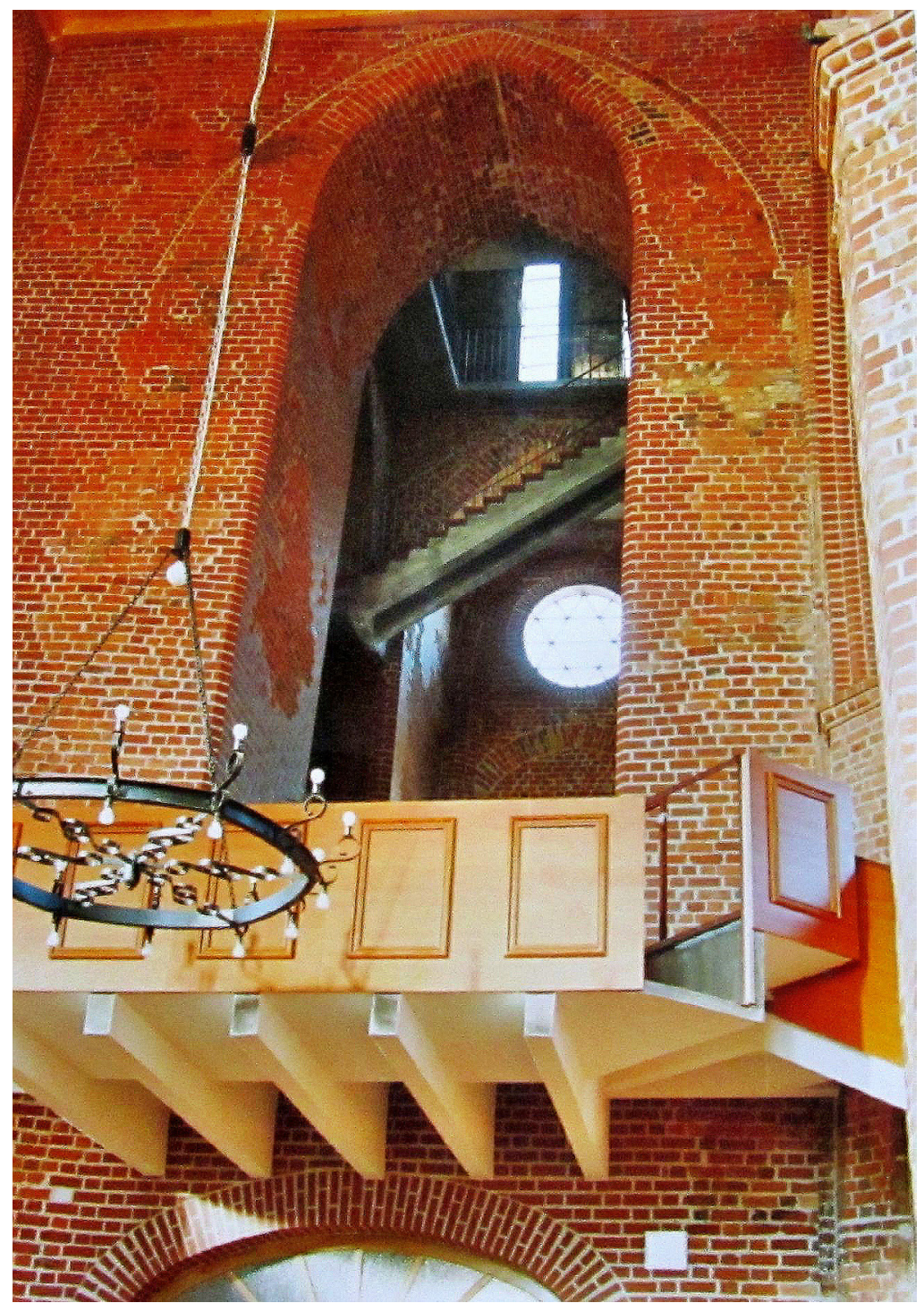

Il. 8. Wolin, kościół pw. św. Mikołaja. Wnętrze, wschodnia ściana wieży z otwartym prześwitem, 1999. Za: AWUOZS, KEZAiB, Waldemar Witek, „Rzymsko-katolicki kościół p.w. św. Mikołaja, Wolin”, Szczecin 1999, fot. 11. 


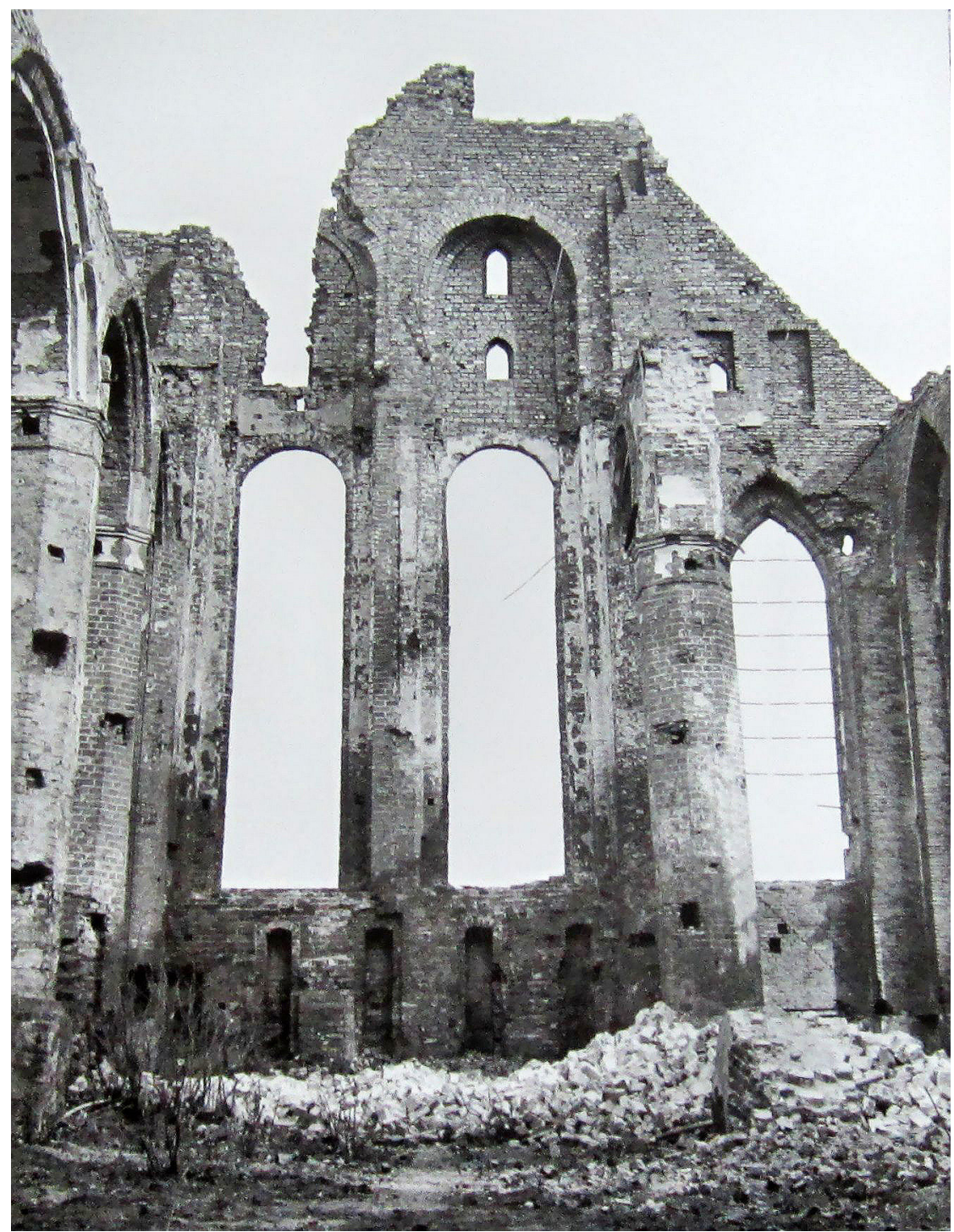

Il. 9. Wolin, kościół pw. św. Mikołaja. Wnętrze, ściana wschodnia, około 1971. (Za: K. Kalita, fot. G. Solecki, „Kościół św. Mikołaja w Wolinie”, fot. 30. 


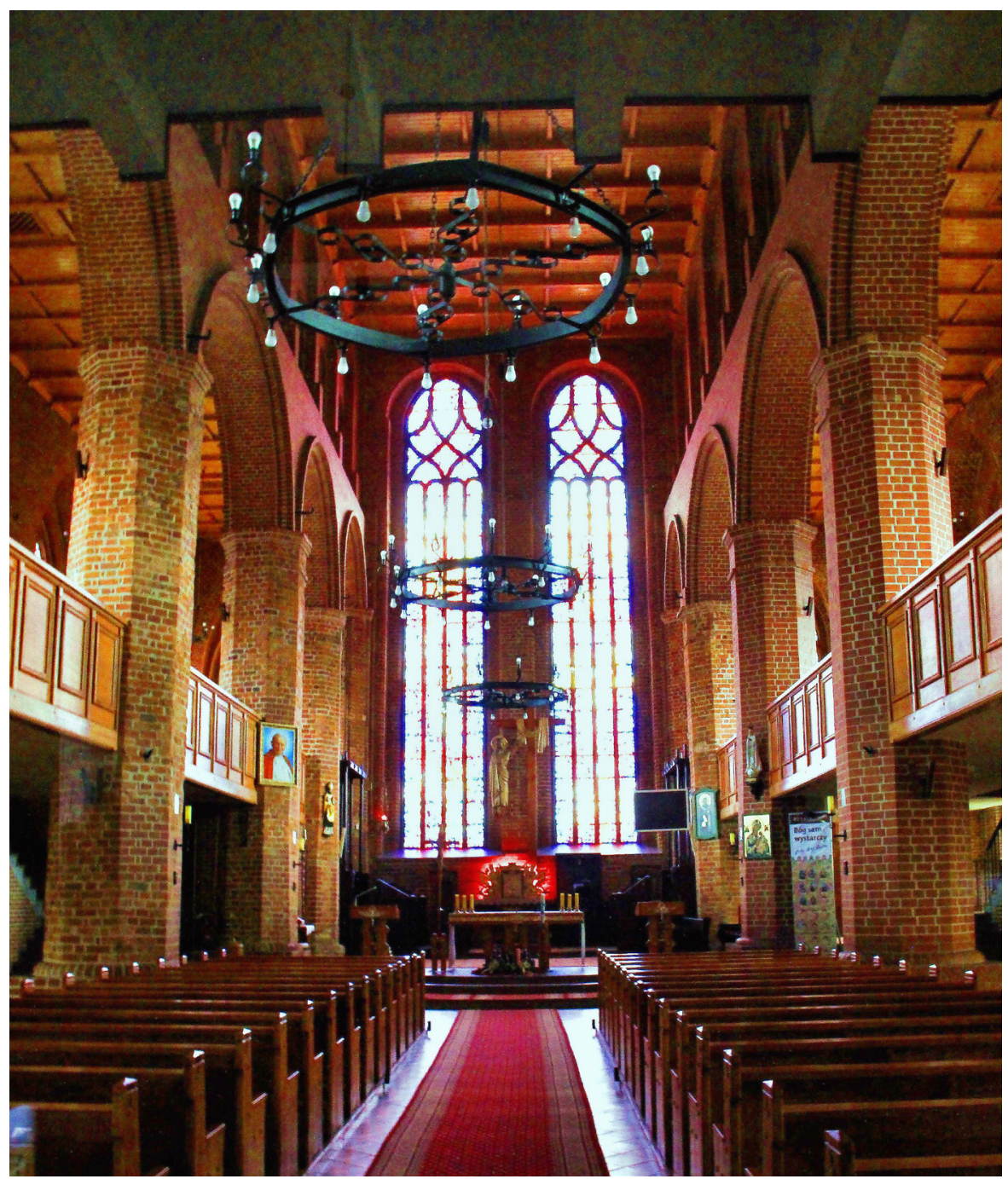

Il. 10. Wolin, kościół pw. św. Mikołaja. Wnętrze, nawa główna, empory w nawach bocznych, zrekonstruowane otwory okienne w ścianie wschodniej, 2014. Fot. J. Gierlasiński 


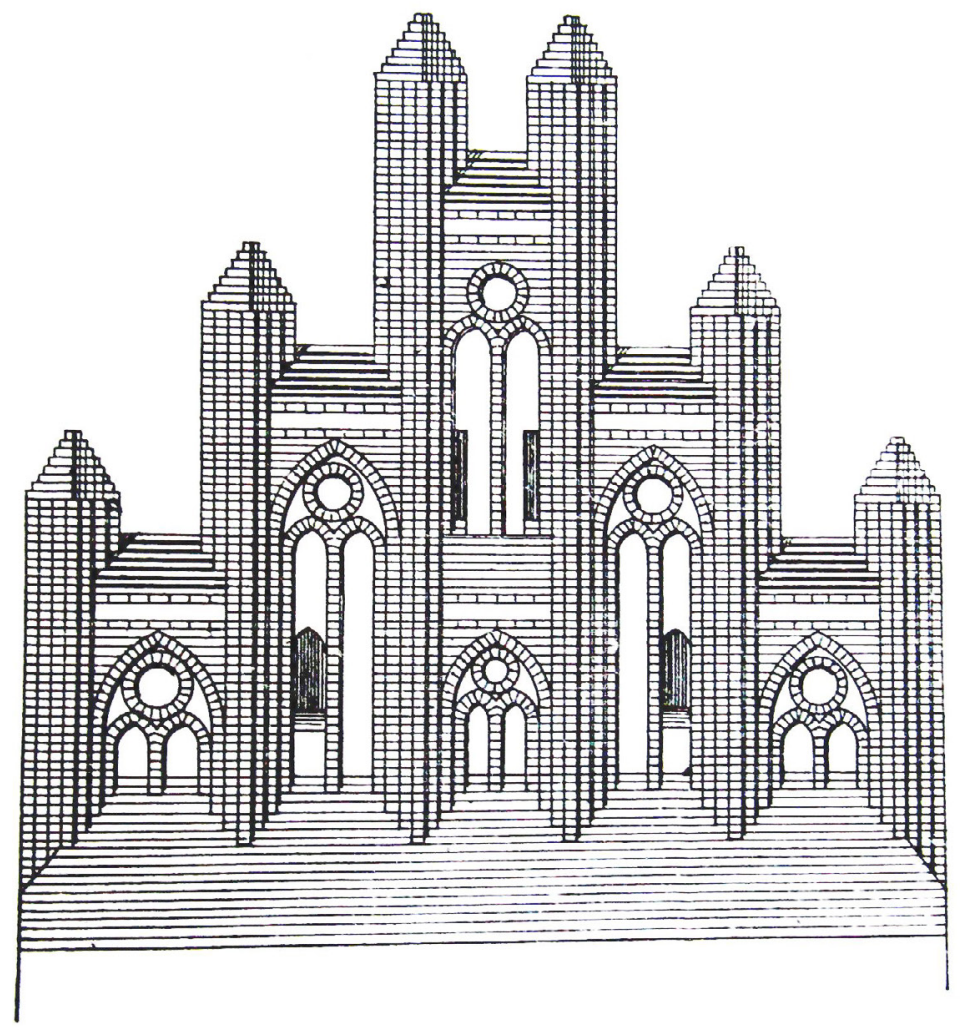

Il. 11. Wolin, kościół pw. św. Mikołaja. Szczyt ściany wschodniej, 1898. Za: H. Lemcke, Die Bauund Kunstdenkmäler der Regierungsbezirks Stettin, z. 4, Der Kreis Usedom - Wollin, Stettin 1900, il. 43 


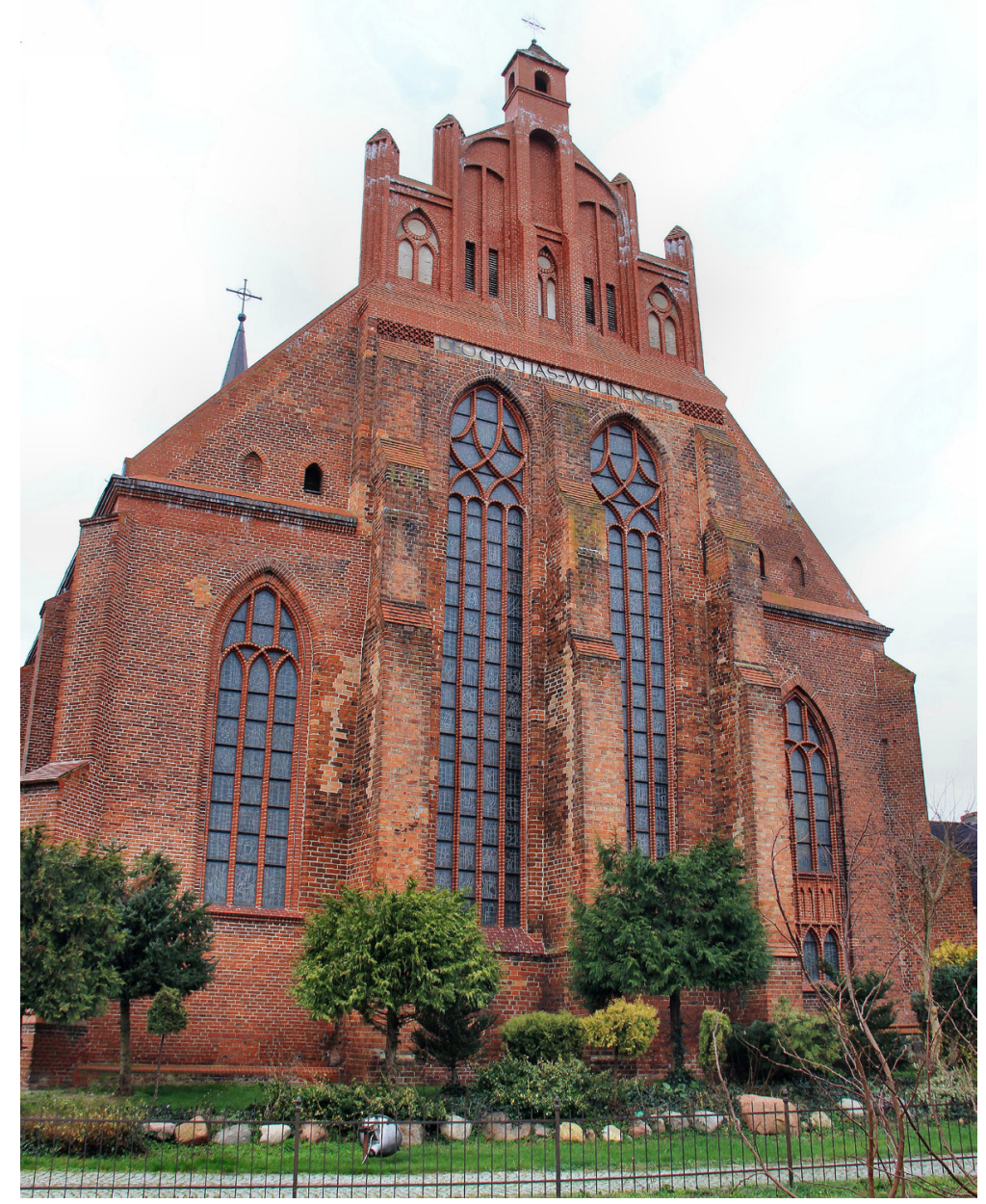

Il. 12. Wolin, kościół pw. św. Mikołaja. Zrekonstruowana ściana wschodnia, 2014. Fot. J. Gierlasiński 


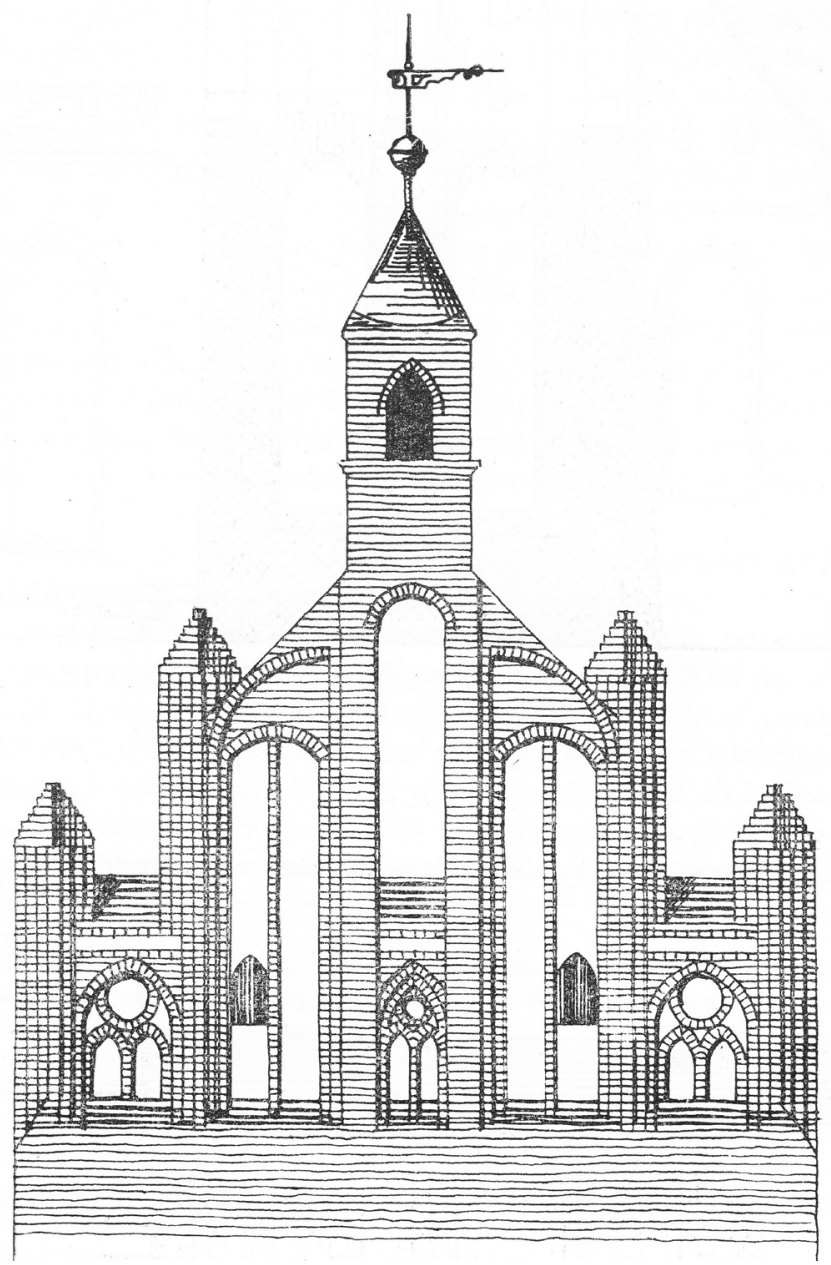

Il. 13. Wolin, kościół pw. św. Mikołaja. Szczyt ściany wschodniej, 1860. Za: H. Lemcke, Die Bauund Kunstdenkmäler, il. 42 


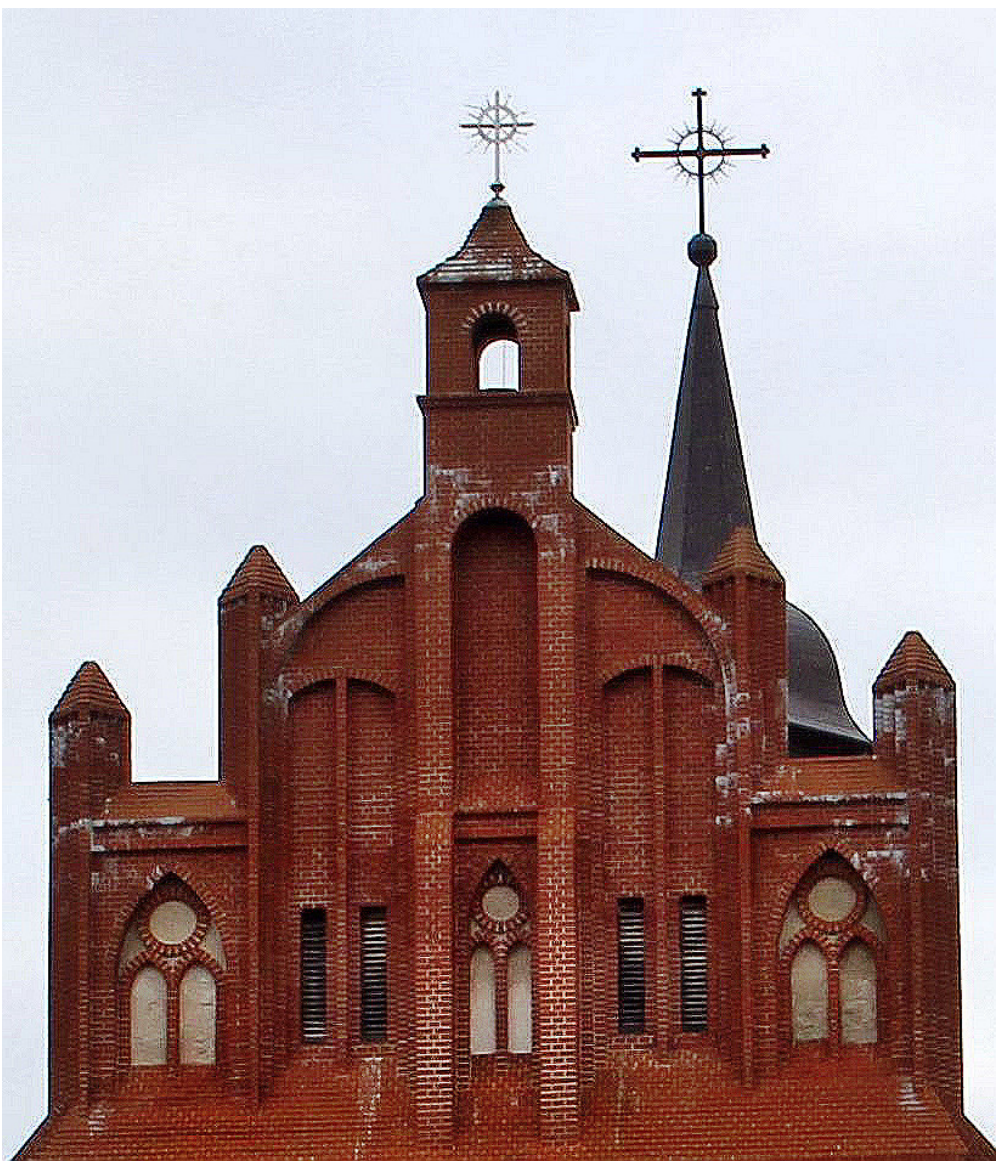

Il. 14. Wolin, kościół pw. św. Mikołaja. Zrekonstruowany szczyt ściany wschodniej, 2014. Fot. J. Gierlasiński 


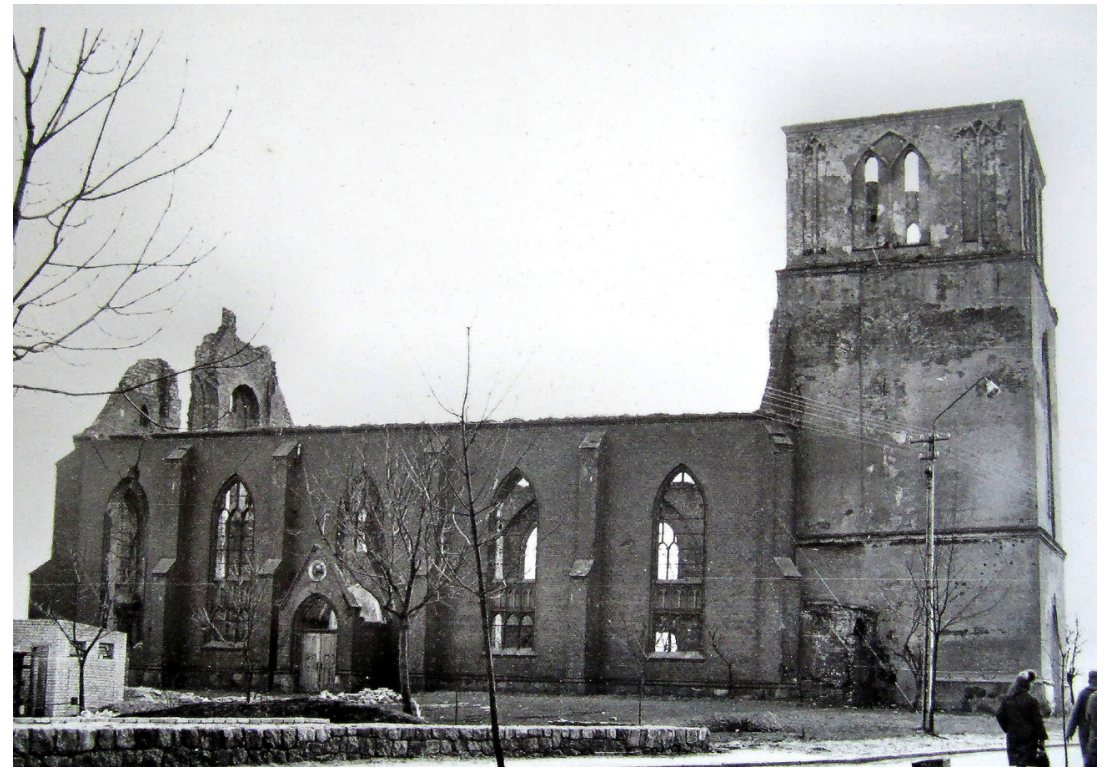

Il. 15. Wolin, kościół pw. św. Mikołaja. Ściana północna i wieża, około 1971. (Za: K. Kalita, fot. G. Solecki, „Kościół św. Mikołaja w Wolinie”, fot. 27.

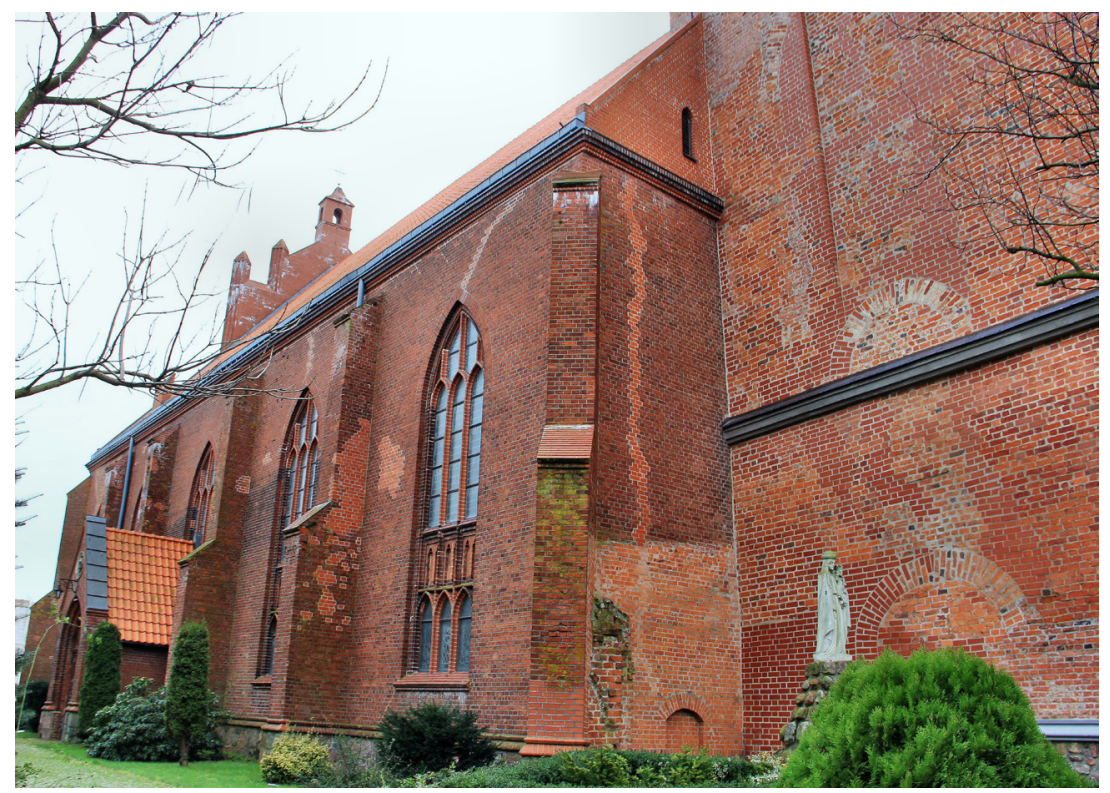

Il. 16. Wolin, kościół pw. św. Mikołaja. Ściana północna, 2014. Fot. J. Gierlasiński 


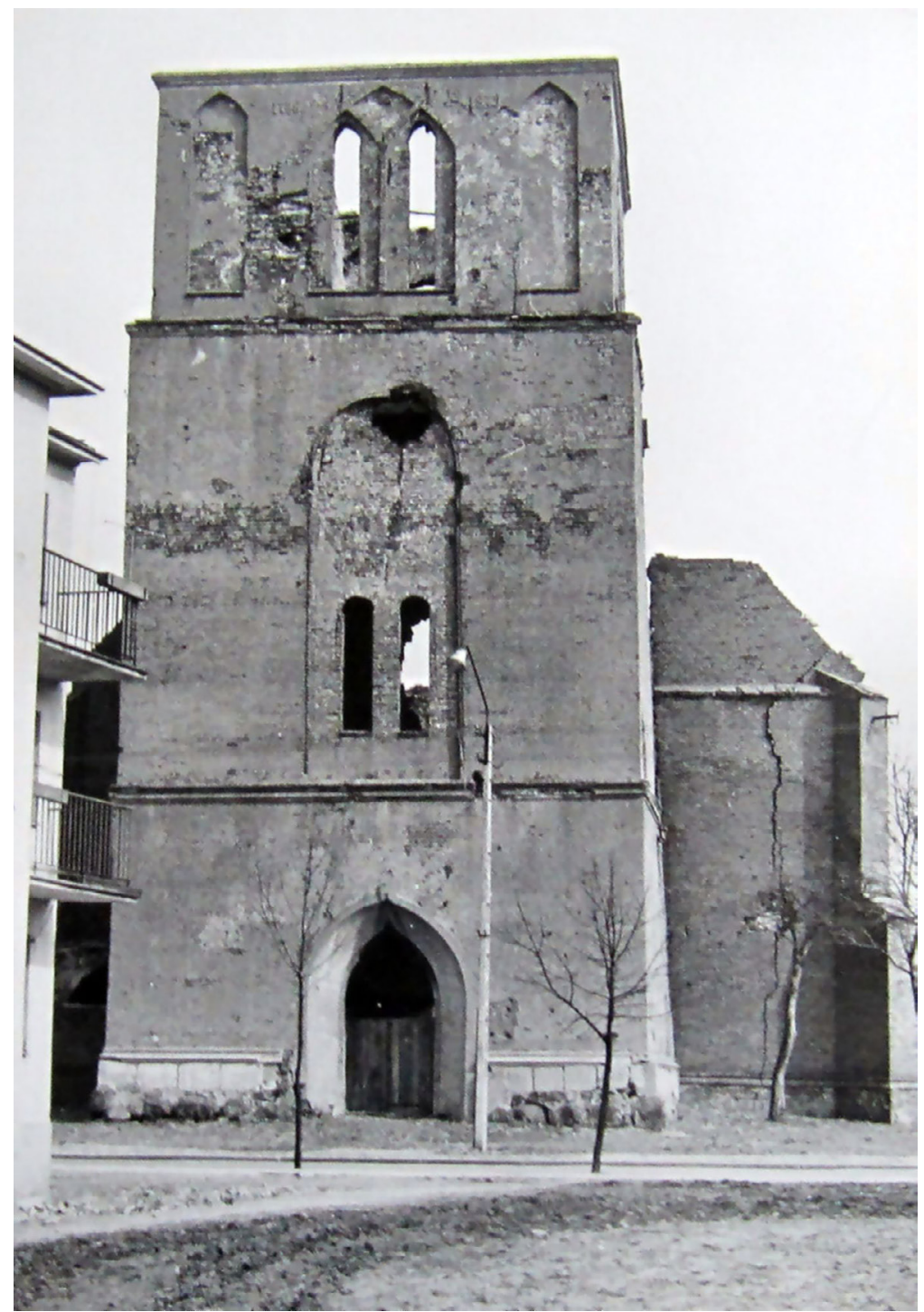

Il. 17. Wolin, kościół pw. św. Mikołaja. Zachodnia elewacja wieży, 1971. Za: K. Kalita, „Kościół św. Mikołaja w Wolinie”. Fot. G. Solecki (K. Kalita, fot. G. Solecki, „Kościół św. Mikołaja w Wolinie”, fot. 22. 


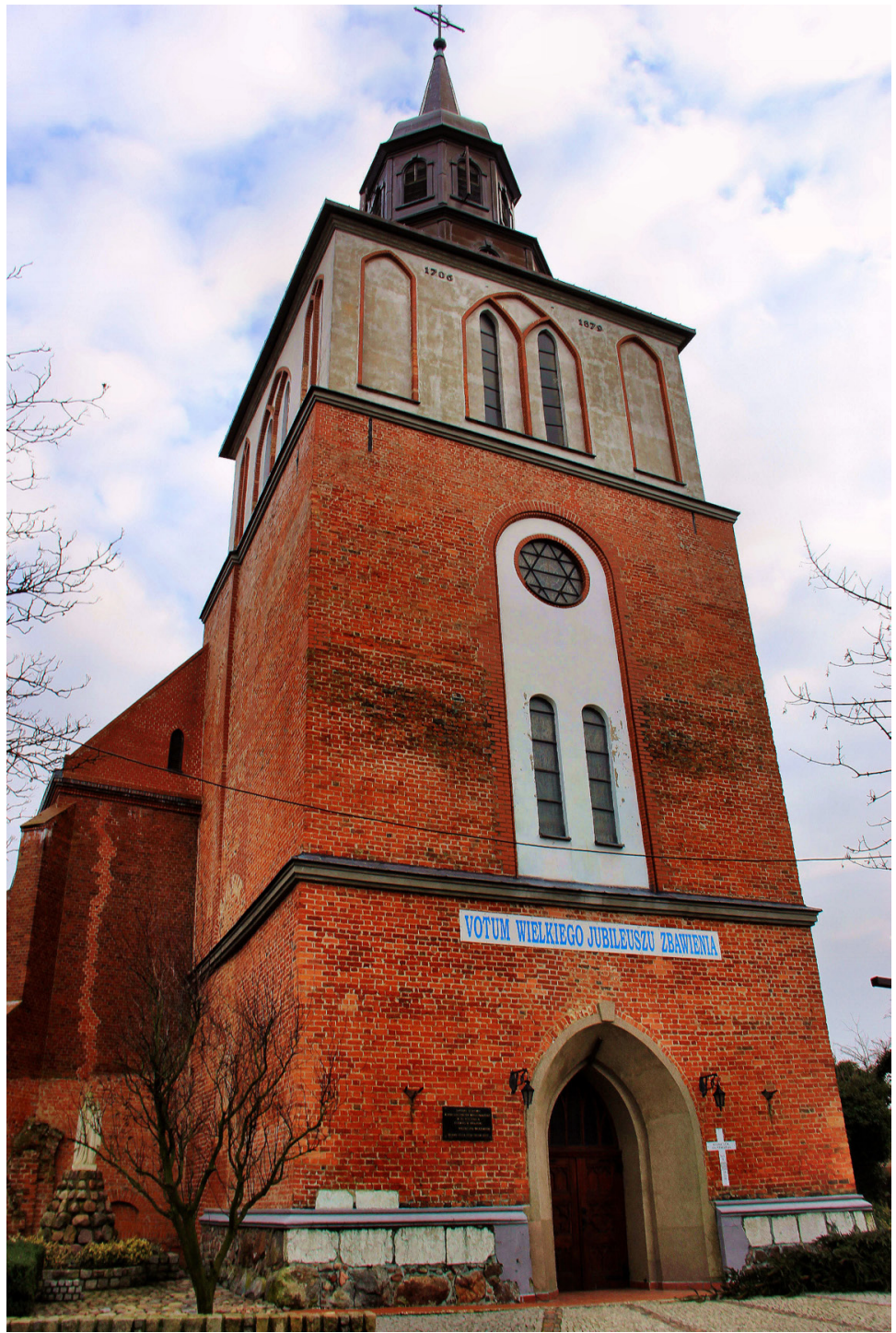

Il. 18. Wolin, kościół pw. św. Mikołaja. Zachodnia elewacja wieży, 2014. Fot. J. Gierlasiński 


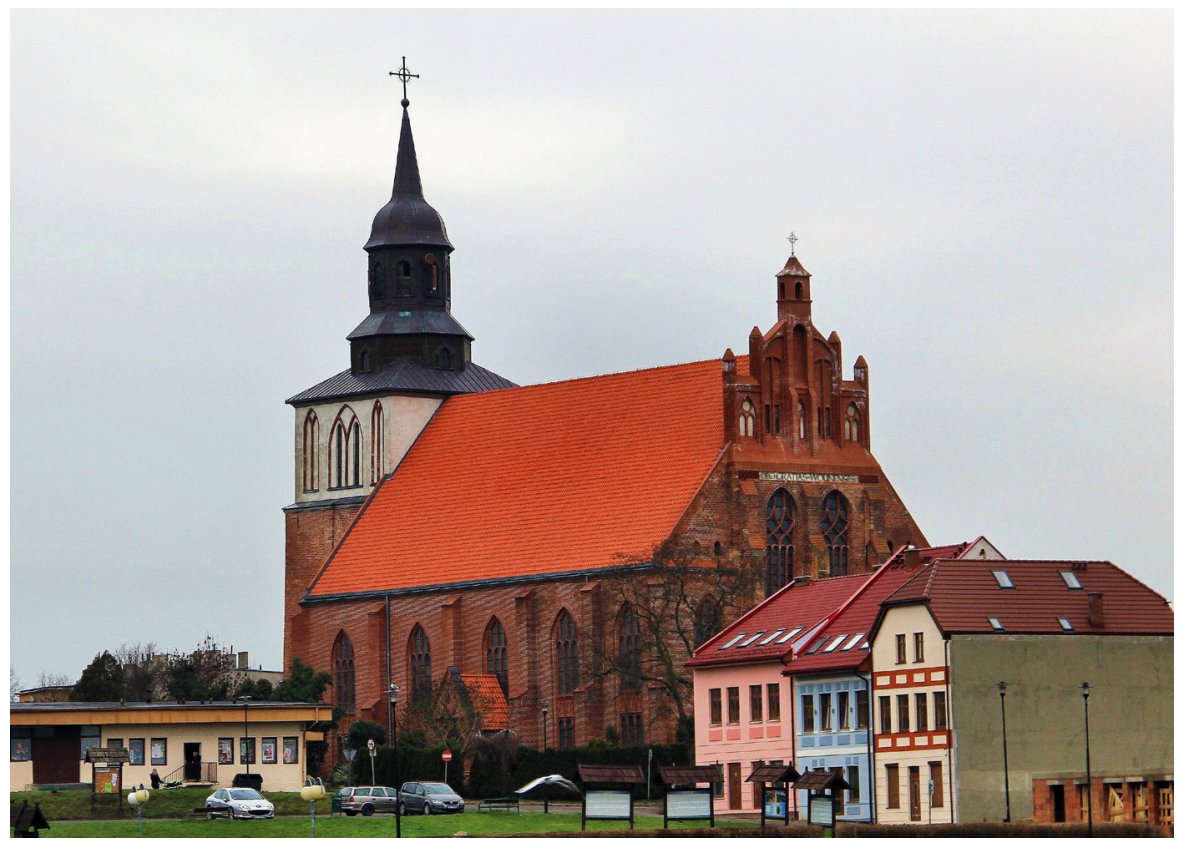

Il. 19. Wolin, kościół pw. św. Mikołaja. 2014. Fot. J. Gierlasiński 